\title{
LEVEL II SCOUR ANALYSIS FOR BRIDGE 25 (ROCHTH00400025) on TOWN HIGHWAY 40, crossing CORPORATION BROOK, ROCHESTER, VERMONT
}

Open-File Report 98-160

Prepared in cooperation with

VERMONT AGENCY OF TRANSPORTATION

and

FEDERAL HIGHWAY ADMINISTRATION

U.S. Department of the Interior U.S. Geological Survey

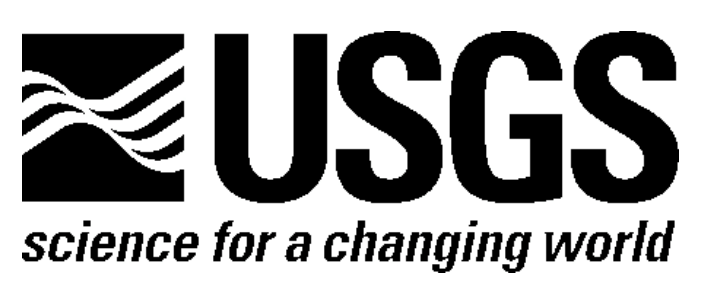




\section{LEVEL II SCOUR ANALYSIS FOR BRIDGE 25 (ROCHTH00400025) on TOWN HIGHWAY 40, crossing CORPORATION BROOK, ROCHESTER, VERMONT \\ By EMILY C. WILD and MATTHEW A. WEBER}

U.S. Geological Survey Open-File Report 98-160

Prepared in cooperation with

VERMONT AGENCY OF TRANSPORTATION and

FEDERAL HIGHWAY ADMINISTRATION 


\title{
U.S. DEPARTMENT OF THE INTERIOR BRUCE BABBITT, Secretary
}

\author{
U.S. GEOLOGICAL SURVEY
}

Thomas J. Casadevall, Acting Director

For additional information write to:

District Chief

U.S. Geological Survey 361 Commerce Way

Pembroke, NH 03275-3718
Copies of this report may be purchased from:

U.S. Geological Survey

Branch of Information Services

Open-File Reports Unit

Box 25286

Denver, CO 80225-0286 


\section{CONTENTS}

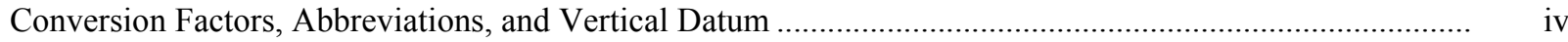

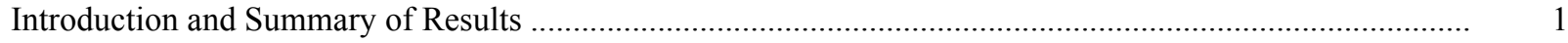

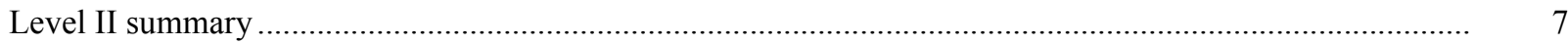

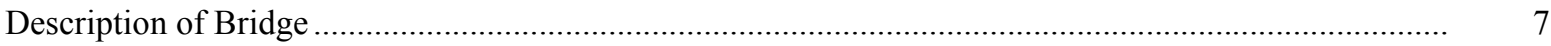

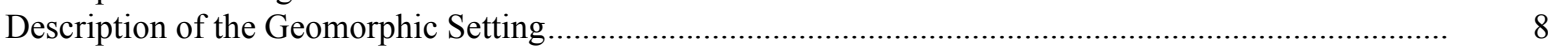

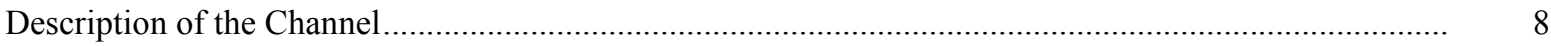

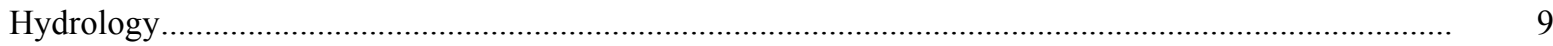

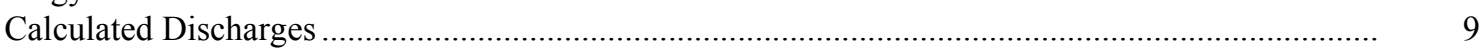

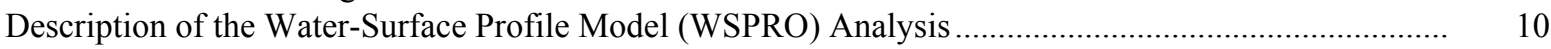

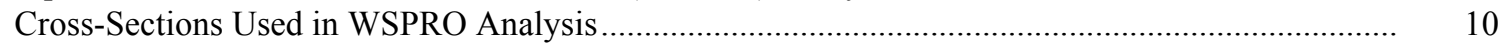

Data and Assumptions Used in WSPRO Model ........................................................................ 11

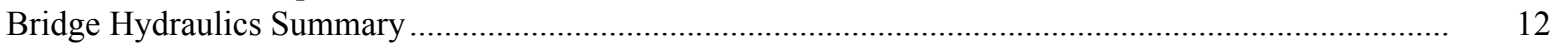

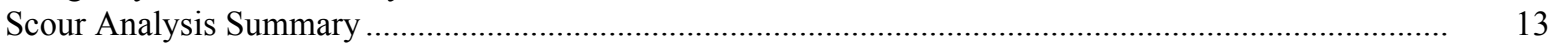

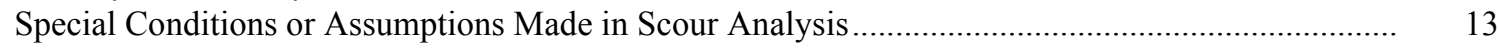

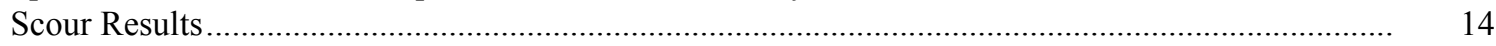

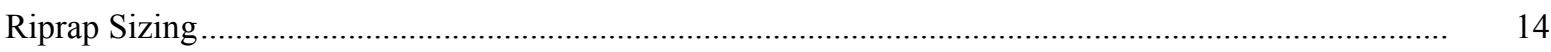

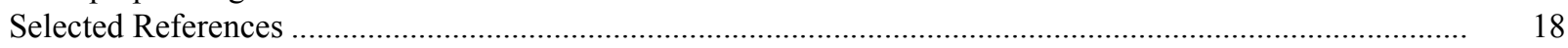

Appendices:

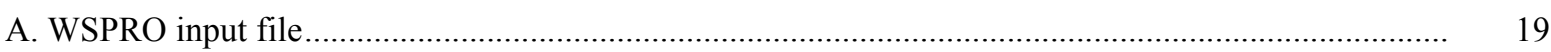

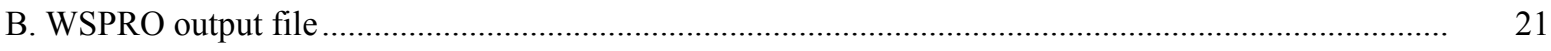

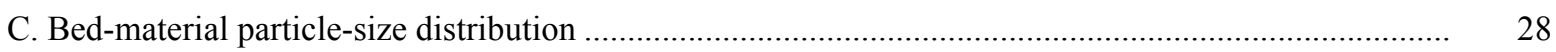

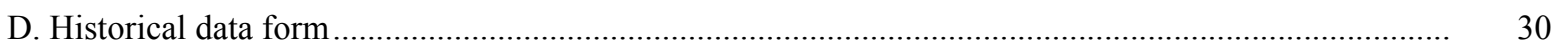

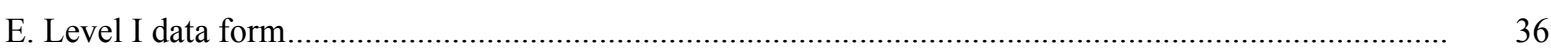

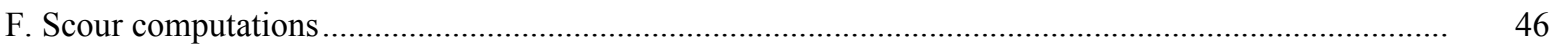

\section{FIGURES}

1. Map showing location of study area on USGS 1:24,000 scale map

2. Map showing location of study area on Vermont Agency of Transportation town highway map

3. Structure ROCHTH00400025 viewed from upstream (July 8, 1996)

4. Downstream channel viewed from structure ROCHTH00400025 (July 8, 1996)

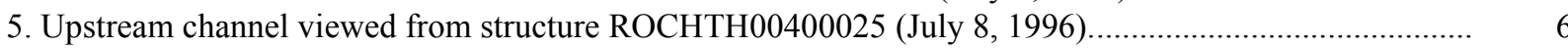

6. Structure ROCHTH00400025 viewed from downstream (July 8, 1996).

7. Water-surface profiles for the 100- and 500-year discharges at structure

ROCHTH00400025 on Town Highway 40, crossing Corporation Brook,

Rochester, Vermont.

8. Scour elevations for the 100- and 500-year discharges at structure

ROCHTH00400025 on Town Highway 40, crossing Corporation Brook,

Rochester, Vermont.

\section{TABLES}

1. Remaining footing/pile depth at abutments for the 100-year discharge at structure ROCHTH00400025 on Town Highway 40, crossing Corporation Brook,

Rochester, Vermont

2. Remaining footing/pile depth at abutments for the 500-year discharge at structure ROCHTH00400025 on Town Highway 40, crossing Corporation Brook, Rochester, Vermont 


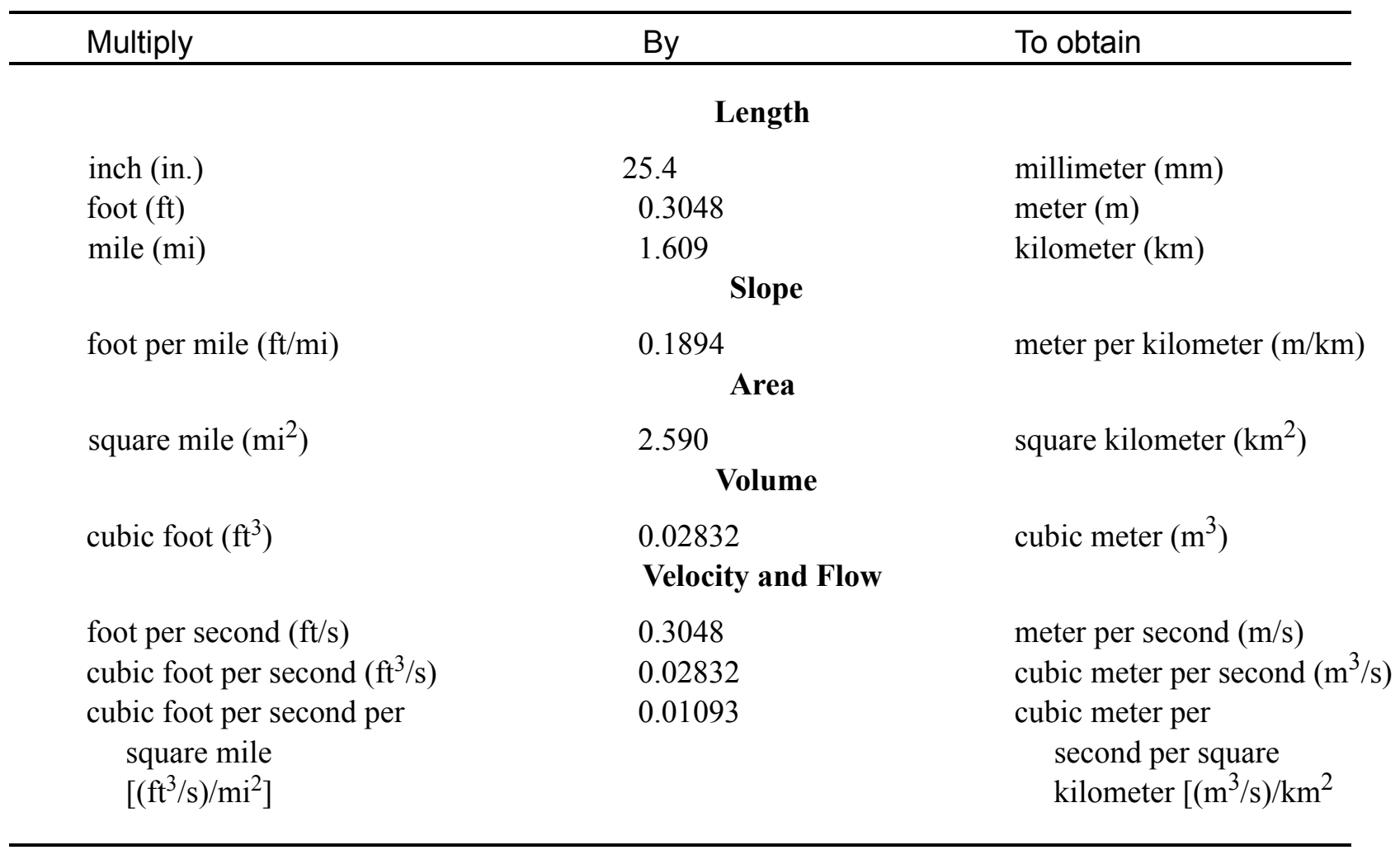

\section{OTHER ABBREVIATIONS}

$\begin{array}{lrlr}\mathrm{BF} & \text { bank full } & \text { LWW } & \text { left wingwall } \\ \mathrm{cfs} & \text { cubic feet per second } & \text { Max } & \text { maximum } \\ \mathrm{D}_{50} & \text { median diameter of bed material } & \text { MC } & \text { main channel } \\ \mathrm{DS} & \text { downstream } & \text { RAB } & \text { right abutment } \\ \mathrm{elev} & \text { elevation } & \text { RABUT } & \text { face of right abutment } \\ \mathrm{f} / \mathrm{p} & \text { flood plain } & \text { RB } & \text { right bank } \\ \mathrm{ft} & \text { square feet } & \text { ROB } & \text { right overbank } \\ \mathrm{ft} / \mathrm{ft} & \text { feet per foot } & \text { RWW } & \text { right wingwall } \\ \mathrm{FEMA} & \text { Federal Emergency Management Agency } & \text { TH } & \text { town highway } \\ \mathrm{FHWA} & \text { Federal Highway Administration } & \text { UB } & \text { under bridge } \\ \mathrm{JCT} & \text { junction } & \text { US } & \text { upstream } \\ \text { LAB } & \text { left abutment } & \text { USGS } & \text { United States Geological Survey } \\ \text { LABUT } & \text { face of left abutment } & \text { VTAOT } & \text { Vermont Agency of Transportation } \\ \text { LB } & \text { left bank } & \text { WSPRO } & \text { water-surface profile model } \\ \text { LOB } & \text { left overbank } & \text { yr } & \text { year }\end{array}$

In this report, the words "right" and "left" refer to directions that would be reported by an observer facing downstream. Sea level: In this report, "sea level" refers to the National Geodetic Vertical Datum of 1929-- a geodetic datum derived from a general adjustment of the first-order level nets of the United States and Canada, formerly called Sea Level Datum of 1929.

In the appendices, the above abbreviations may be combined. For example, USLB would represent upstream left bank. 


\title{
LEVEL II SCOUR ANALYSIS FOR BRIDGE 25 (ROCHTH00400025) ON TOWN HIGHWAY 40, CROSSING CORPORATION BROOK, ROCHESTER, VERMONT
}

\author{
By Emily C. Wild and Matthew A. Weber
}

\section{INTRODUCTION AND SUMMARY OF RESULTS}

This report provides the results of a detailed Level II analysis of scour potential at structure ROCHTH00400025 on Town Highway 40 crossing Corporation Brook, Rochester, Vermont (figures 1-8). A Level II study is a basic engineering analysis of the site, including a quantitative analysis of stream stability and scour (FHWA, 1993). Results of a Level I scour investigation also are included in appendix E of this report. A Level I investigation provides a qualitative geomorphic characterization of the study site. Information on the bridge, from Vermont Agency of Transportation files, was compiled prior to conducting Level I and Level II analyses and is found in appendix D.

The site is in the Green Mountain section of the New England physiographic province in central Vermont. The 4.97- $\mathrm{mi}^{2}$ drainage area is in a predominantly rural and forested basin. In the vicinity of the study site, the surface cover is forest on the upstream left and right overbanks, and the downstream left overbank. On the downstream right overbank, the surface cover is predominately brushland.

In the study area, Corporation Brook has an incised, sinuous channel with a slope of approximately $0.04 \mathrm{ft} / \mathrm{ft}$, an average channel top width of $37 \mathrm{ft}$ and an average bank height of $6 \mathrm{ft}$. The channel bed material ranges from gravel to boulders with a median grain size $\left(\mathrm{D}_{50}\right)$ of $101 \mathrm{~mm}(0.332 \mathrm{ft})$. The geomorphic assessment at the time of the Level I site visit on April 12, 1995 and Level I and II site visit on July 8, 1996, indicated that the reach was stable.

The Town Highway 40 crossing of Corporation Brook is a 31-ft-long, one-lane bridge consisting of a 26-foot steel stringer span (Vermont Agency of Transportation, written communication, March 22, 1995). The opening length of the structure parallel to the bridge face is $24 \mathrm{ft}$. The bridge is supported by vertical, concrete abutments. The channel is skewed approximately 15 degrees to the opening while the opening-skew-to-roadway is 15 degrees. 
A scour hole $1.0 \mathrm{ft}$ deeper than the mean thalweg depth was observed in the channel at the downstream bridge face during the Level I assessment. Additionally, it was observed that the left abutment footing was exposed $1.0 \mathrm{ft}$ and the right abutment footing was exposed 2.0 $\mathrm{ft}$. Scour countermeasures at the site included type-1 stone fill (less than 12 inches diameter) along the upstream left and right banks and the downstream left bank. Type-2 stone fill (less than 36 inches diameter) scour protection extended along the downstream right bank and the upstream and downstream ends of the abutments. Additional details describing conditions at the site are included in the Level II Summary and appendices D and $\mathrm{E}$.

Scour depths and recommended rock rip-rap sizes were computed using the general guidelines described in Hydraulic Engineering Circular 18 (Richardson and Davis, 1995) for the 100- and 500-year discharges. In addition, the incipient roadway-overtopping discharge was determined and analyzed as another potential worst-case scour scenario. Total scour at a highway crossing is comprised of three components: 1) long-term streambed degradation; 2) contraction scour (due to accelerated flow caused by a reduction in flow area at a bridge) and; 3 ) local scour (caused by accelerated flow around piers and abutments). Total scour is the sum of the three components. Equations are available to compute depths for contraction and local scour and a summary of the results of these computations follows.

Contraction scour for all modelled flows ranged from 0.1 to $1.5 \mathrm{ft}$. The worst-case contraction scour occurred at the 500-year discharge. Left abutment scour ranged from 6.5 to $7.0 \mathrm{ft}$. The worst-case left abutment scour occurred at the 500-year discharge. Right abutment scour ranged from 5.6 to $6.0 \mathrm{ft}$. The worst-case right abutment scour occurred at the incipient roadway-overtopping discharge. Additional information on scour depths and depths to armoring are included in the section titled "Scour Results". Scoured-streambed elevations, based on the calculated scour depths, are presented in tables 1 and 2. A crosssection of the scour computed at the bridge is presented in figure 8. Scour depths were calculated assuming an infinite depth of erosive material and a homogeneous particle-size distribution.

It is generally accepted that the Froehlich equation (abutment scour) gives "excessively conservative estimates of scour depths" (Richardson and Davis, 1995, p. 46). Usually, computed scour depths are evaluated in combination with other information including (but not limited to) historical performance during flood events, the geomorphic stability assessment, existing scour protection measures, and the results of the hydraulic analyses. Therefore, scour depths adopted by VTAOT may differ from the computed values documented herein. 


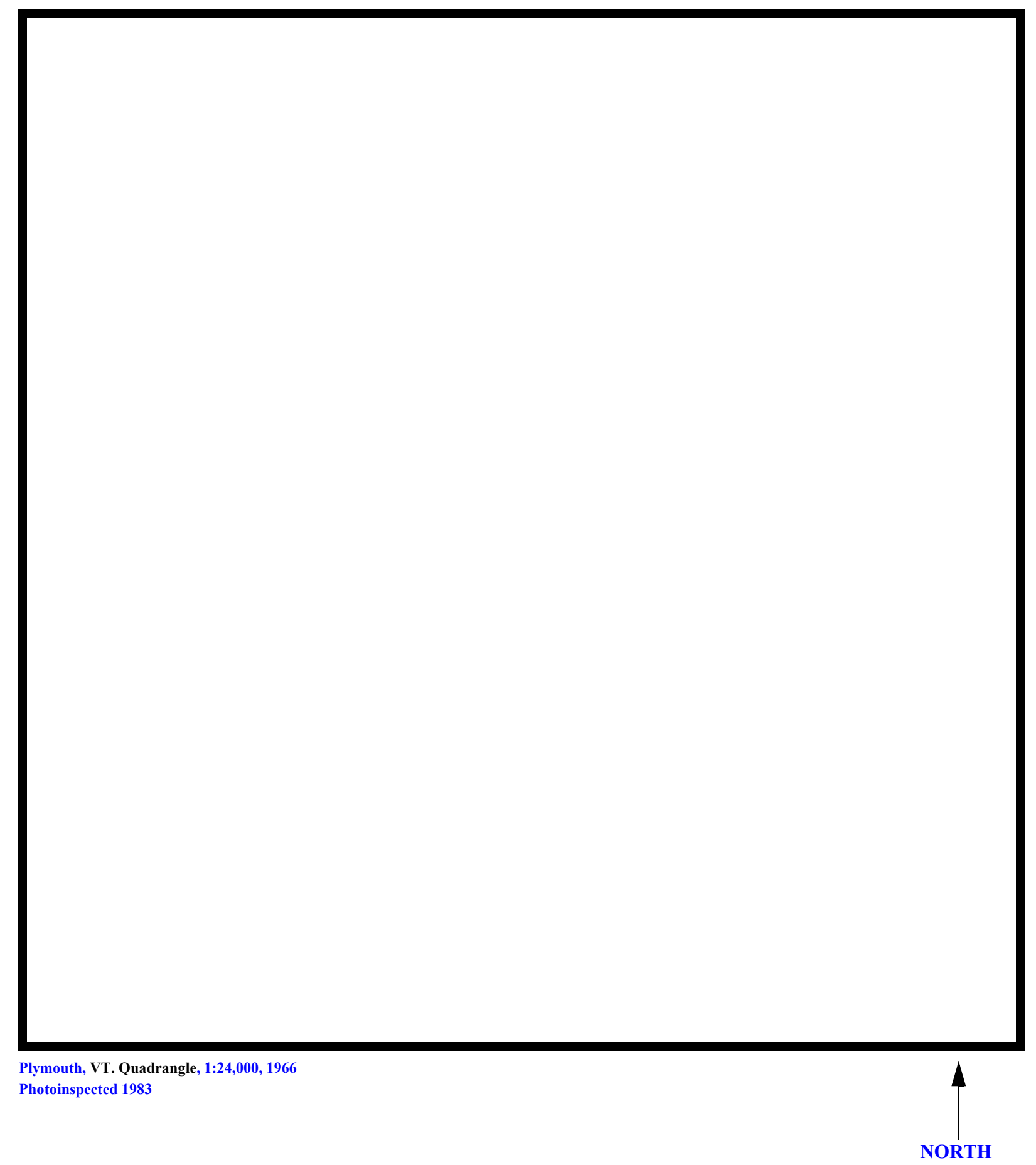

Figure 1. Location of study area on USGS 1:24,000 scale map. 
Figure 2. Location of study area on Vermont Agency of Transportation town highway map. 

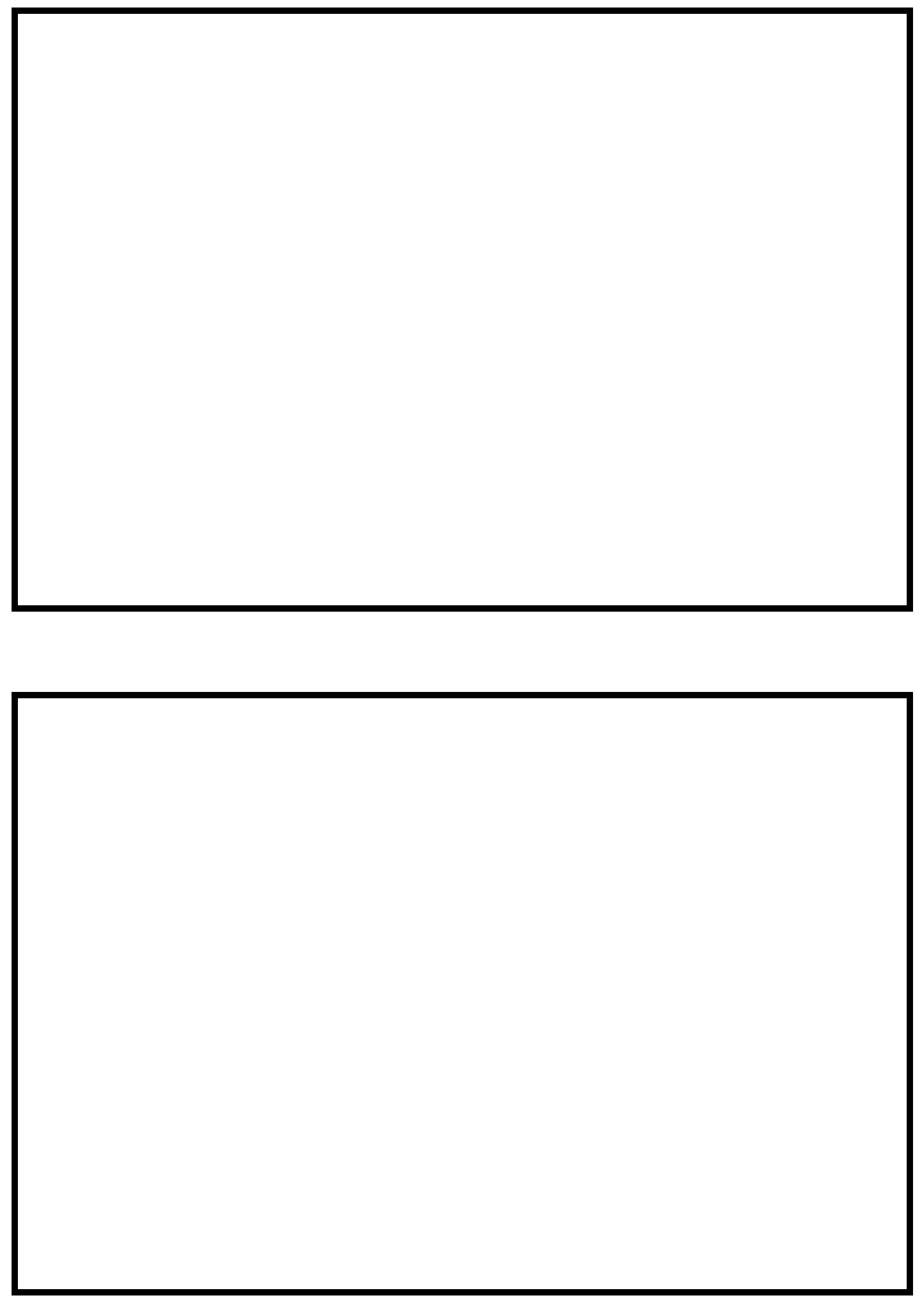

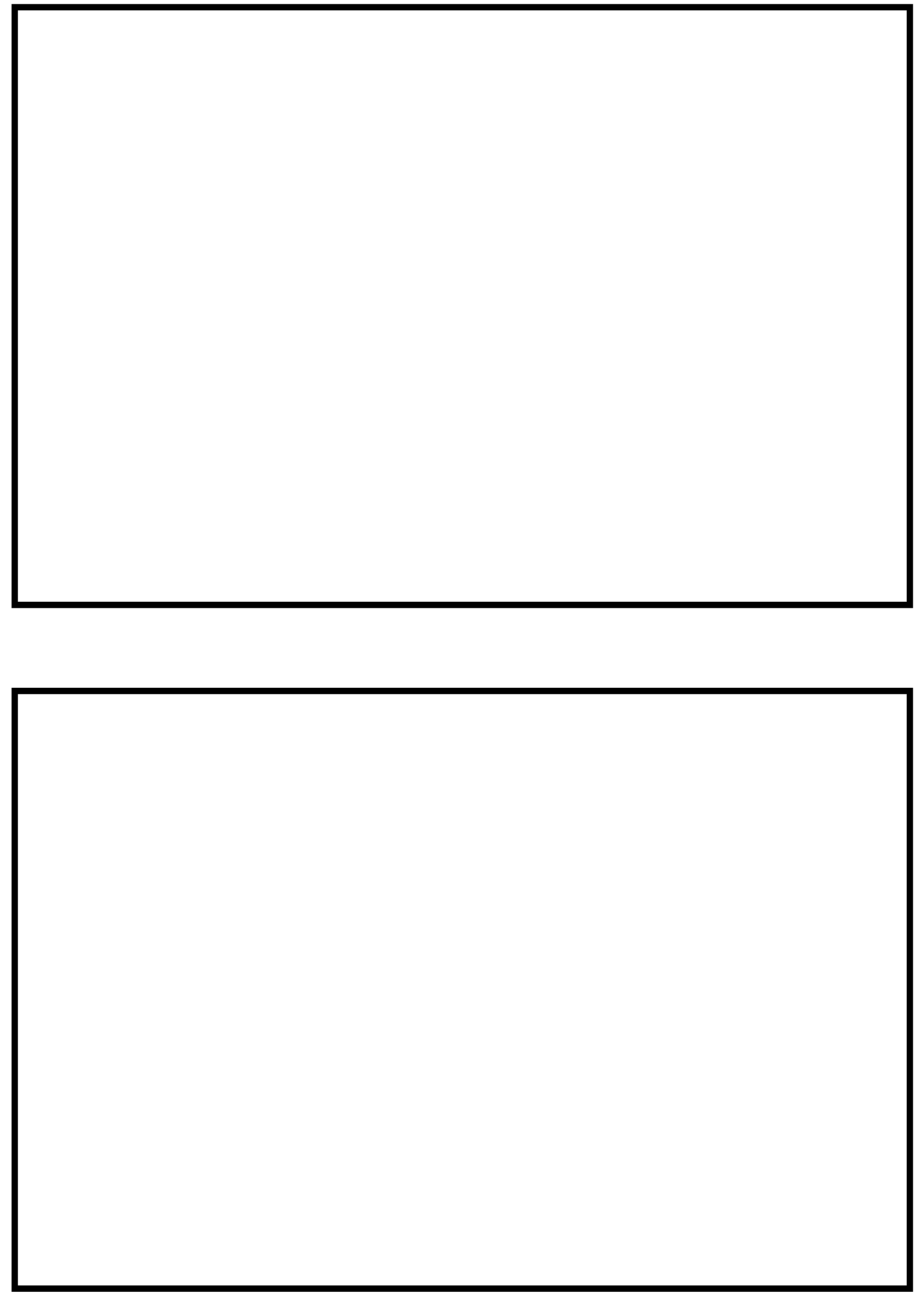


\section{LEVEL II SUMMARY}

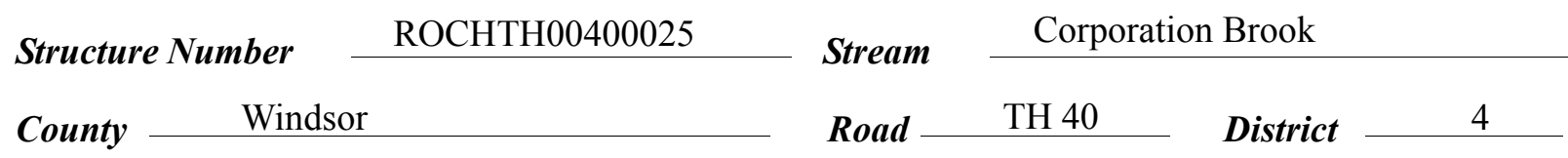

\section{Description of Bridge}

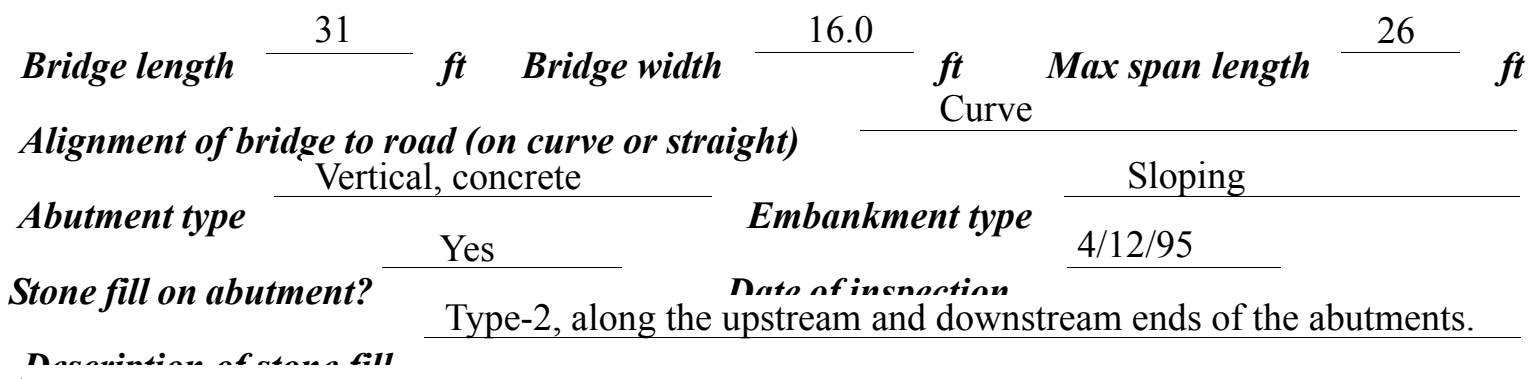

Abutments are laid-up stone and faced with concrete. There is a one foot deep scour hole in the channel at the downstream bridge face.

Y̌es

15

No

Is bridge skewed to flood flow according to 'survey?

Angle

$4 / 12 / 95$

0

Debris accumulation on bridge at time of Level I or Level II site visit:

\begin{tabular}{|c|c|c|c|}
\hline & $\begin{array}{c}\text { Date of incnortion } \\
\underline{0}\end{array}$ & $\begin{array}{l}\text { Percent of olhminal } \\
\text { blocked inortsontatly }\end{array}$ & $\begin{array}{l}\text { Percent of a nel } \\
\text { blocked verticatty }\end{array}$ \\
\hline Level I & 0 & Moderat & e. There \\
\hline $\begin{array}{l}\text { Level II } \\
\text { bridge. }\end{array}$ & is some de & ught on the banks upst & d downstream of the \\
\hline
\end{tabular}

None, 4/12/95.

Doscriho any, foaturos noar ar at tho hridos that mav, affoct flou, (includo ahsorvation dato) 


\section{Description of the Geomorphic Setting}

General topography The channel is located within a high relief valley with a narrow

floodplain.

Geomorphic conditions at bridge site: downstream (DS), upstream (US)

Date of inspection $\quad 4 / 12 / 95$

DS left: $\quad$ Moderately sloped overbank

DS right: $\quad$ Steep valley wall

US left: $\quad$ Moderately sloped overbank

US right: $\quad$ Steep valley wall

\section{Description of the Channel}

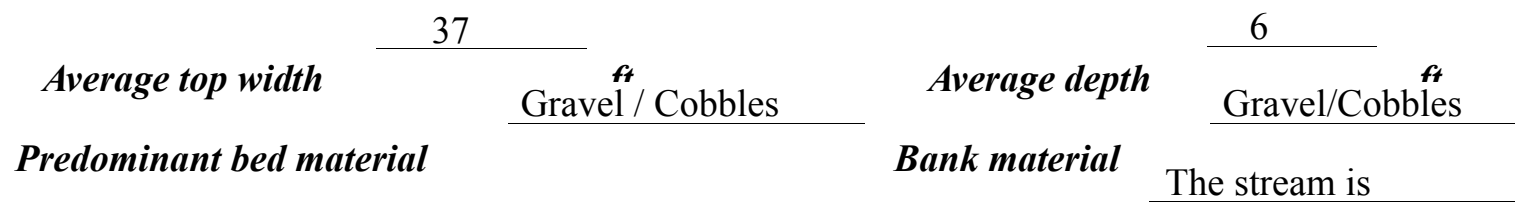

perennial and sinuous with semi-alluvial, stable channel boundäries."

$4 / 12 / 95$

Vegetative co 1 Trees

DS left: $\quad$ Brush and shrubs with a few trees

DS right: $\quad$ Trees

US left: $\quad$ Trees

US right: $\quad$ Yes

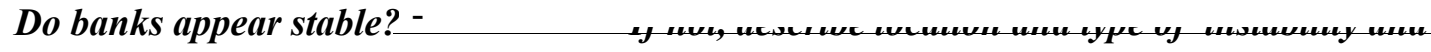

date of observation.

None, 4/12/95.

Describe any obstructions in channel and date of observation. 


\section{Hydrology}

Drainage area $\stackrel{4.97}{\boldsymbol{m i}^{2}}$

Percentage of drainage area in physiographic provinces: (approximate)

Physiographic province/section

New England/Green Mountain
Percent of drainage area 100

Is drainage area considered rural or urban? — Rural _ Describe any significant urbanization:

Is there a USGS gage on the stream of interest?

No

USGS gage description
USGS gage number
Gage drainage area

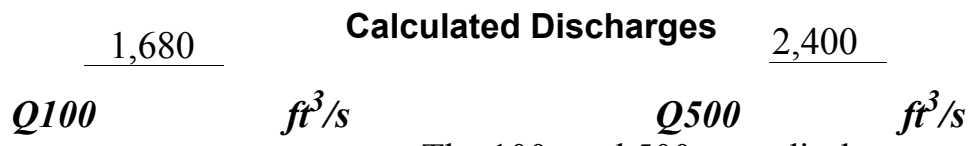

The 100- and 500-year discharges are based on a

drainage area relationship.[(5.0/6.0)exp 0.67] with flood frequency estimates available from the VTAOT database (written communication, May 1995) for bridge number 16 in Rochester. The drainage area above bridge number 16 is 6.0 square miles. These area adjusted values were within a range defined by flood frequency curves developed from several empirical methods (Benson, 1962; Johnson and Tasker, 1974; FHWA, 1983; Potter, 1957a\&b; Talbot, 1887). Each curve was extended graphically to the 500 -year discharge. 


\section{Description of the Water-Surface Profile Model (WSPRO) Analysis}

Datum for WSPRO analysis (USGS survey, sea level, VTAOT plans)

USGS survey

Datum tie between USGS survey and VTAOT plans

None

Description of reference marks used to determine USGS datum. $\quad$ RM1 is a chiseled X on

top of the downstream end of the right abutment (elev. $497.92 \mathrm{ft}$, arbitrary survey datum). RM2

is a chiseled X on top of the upstream end of the left abutment (elev. $499.27 \mathrm{ft}$, arbitrary survey

datum). RM3 is a National Forest Service Land Survey Marker (elev. 506.83, arbitrary survey

datum), located 150 feet upstream on the right bank.

\section{Cross-Sections Used in WSPRO Analysis}

\begin{tabular}{cccl}
\hline${ }^{1}$ Cross-section & $\begin{array}{c}\text { Section } \\
\text { Reference } \\
\text { Distance } \\
\text { (SRD) } \text { in feet }\end{array}$ & $\begin{array}{c}{ }^{2} \text { Cross-section } \\
\text { development }\end{array}$ & \multicolumn{1}{c}{ Comments } \\
\hline EXITX & -26 & 1 & $\begin{array}{l}\text { Exit section } \\
\text { Downstream Full-valley } \\
\text { section (Templated from } \\
\text { EXITX) }\end{array}$ \\
BRIDG & 0 & 2 & $\begin{array}{l}\text { Bridge section } \\
\text { Road Grade section }\end{array}$ \\
RDWAY & 0 & 1 & $\begin{array}{l}\text { Modelled Approach sec- } \\
\text { tion (Templated from } \\
\text { APTEM }\end{array}$ \\
& 10 & 1 & $\begin{array}{l}\text { APTEM) } \\
\text { Approach section as sur- } \\
\text { veyed (Used as a tem- } \\
\text { plate) }\end{array}$ \\
\hline
\end{tabular}

${ }^{1}$ For location of cross-sections see plan-view sketch included with Level I field form, Appendix E. For more detail on how cross-sections were developed see WSPRO input file. 


\section{Data and Assumptions Used in WSPRO Model}

Hydraulic analyses of the reach were done by use of the Federal Highway Administration's WSPRO step-backwater computer program (Shearman and others, 1986, and Shearman, 1990). The analyses reported herein reflect conditions existing at the site at the time of the study. Furthermore, in the development of the model it was necessary to assume no accumulation of debris or ice at the site. Results of the hydraulic model are presented in the Bridge Hydraulic Summary, appendix B, and figure 7.

Channel roughness factors (Manning's " $n$ ") used in the hydraulic model were estimated using field inspections at each cross section following the general guidelines described by Arcement and Schneider (1989). Final adjustments to the values were made during the modelling of the reach. Channel " $\mathrm{n}$ " values for the reach ranged from 0.055 to 0.065 , and overbank " $n$ " values ranged from 0.065 to 0.075 .

Critical depth at the exit section (EXITX) was assumed as the starting water surface for each modelled discharge. Normal depth was computed by use of the slope-conveyance method outlined in the user's manual for WSPRO (Shearman, 1990) which resulted in a supercritical solution, but within 0.3 feet of critical depth. The slope used was $0.0400 \mathrm{ft} / \mathrm{ft}$, which was calculated from thalweg points surveyed downstream.

The surveyed approach section (APTEM) was moved along the approach channel slope $(0.0579 \mathrm{ft} / \mathrm{ft})$ to establish the modelled approach section (APPRO), one bridge length upstream of the upstream face as recommended by Shearman and others (1986). This location provides a consistent method for determining scour variables.

For the incipient roadway-overtopping discharge, WSPRO assumed critical depth at the bridge section. A supercritical model was developed for this discharge. After analyzing the supercritical and subcritical profiles for the incipient-overtopping discharge, it was assumed that the water surface profile passes through critical depth within the bridge opening. Thus, the assumption of critical depth at the bridge is a satisfactory solution. 


\section{Bridge Hydraulics Summary}

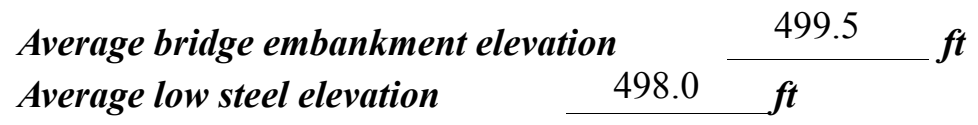

$$
\text { 100-year discharge } \quad 1,680 \quad \mathrm{ft}^{3} / \mathrm{s}
$$

Water-surface elevation in bridge opening $\quad 498.0 \quad f t$

Road overtopping? ___ Yes Discharge over road __ $297 \quad \mathrm{ft}^{3} / \mathrm{s}$

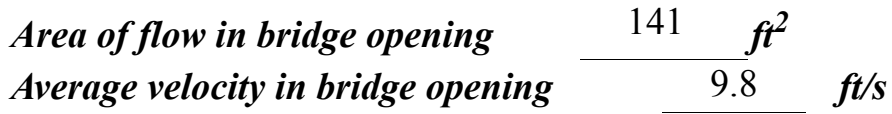

$\begin{array}{llll}\text { Maximum WSPRO tube velocity at bridge } & 20.4 \mathrm{ft} / \mathrm{s}\end{array}$

Water-surface elevation at Approach section with bridge $\quad 500.9$

Water-surface elevation at Approach section without bridge $\quad \overline{498.8}$

Amount of backwater caused by bridge $\quad 2.1 \quad$ it

500-year discharge $\quad 2,400 \quad \mathrm{ft}^{3} / \mathrm{s}$

Water-surface elevation in bridge opening $\quad 498.0 \mathrm{ft}$

$\begin{array}{llllll}\text { Road overtopping? ___ Yes Discharge over road __ } & 673 & \mathrm{ft}^{3} / \mathrm{s}\end{array}$

Area of flow in bridge opening $\quad 142 \quad \mathrm{ft}^{2}$

Average velocity in bridge opening $12.2 \mathrm{ft} / \mathrm{s}$

Maximum WSPRO tube velocity at bridge 14.7 's

Water-surface elevation at Approach section with bridge 501.6

Water-surface elevation at Approach section without bridge $\quad 500.1$

Amount of backwater caused by bridge $\quad 1.5$,t

Incipient overtopping discharge $\quad 1,150 \quad \mathrm{ft}^{3} / \mathrm{s}$

Water-surface elevation in bridge opening 496.1 t

Area of flow in bridge opening $\quad 98 \quad \mathbf{f t}^{2}$

Average velocity in bridge opening $\quad 11.8 \quad \mathrm{ft} / \mathrm{s}$

Maximum WSPRO tube velocity at bridge $\quad 14.9 \mathrm{ft} / \mathrm{s}$

Water-surface elevation at Approach section with bridge

Water-surface elevation at Approach section without bridge

Amount of backwater caused by bridge $\quad 1.3$, t

499.0

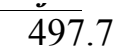




\section{Scour Analysis Summary}

\section{Special Conditions or Assumptions Made in Scour Analysis}

Scour depths were computed using the general guidelines described in Hydraulic Engineering Circular 18 (Richardson and Davis, 1995). Scour depths were calculated assuming an infinite depth of erosive material and a homogeneous particle-size distribution. The results of the scour analyses for the 100- and 500-year discharges are presented in tables 1 and 2 and the scour depths are shown graphically in figure 8 .

Contraction scour for the incipient roadway-overtopping discharge was computed by use of the Laursen clear-water contraction scour equation (Richardson and Davis, 1995, p. 32 , equation 20). At this site, the 100-year discharge resulted in unsubmerged orifice flow and the 500-year discharge resulted in submerged orifice flow. Contraction scour at bridges with orifice flow is best estimated by use of the Chang pressure-flow scour equation (oral communication, J. Sterling Jones, October 4, 1996). Thus, contraction scour for these discharges was computed by use of the Chang equation (Richardson and Davis, 1995, p. 145-146). The streambed armoring depths computed suggest that armoring will not limit the depth of contraction scour.

For comparison, contraction scour for the 100-year and 500-year discharges was computed by use of the Laursen clear-water contraction scour equation and the Umbrell pressure-flow equation (Richardson and Davis, 1995, p. 144). Contraction scour for the 100year discharge was computed by substituting an estimate for the depth of flow at the downstream bridge face in the contraction scour equations. Results with respect to these computations are presented in appendix F.

Abutment scour was computed by use of the Froehlich equation (Richardson and Davis, 1995, p. 48, equation 28). Variables for the Froehlich equation include the Froude number of the flow approaching the embankments, the length of the embankment blocking flow, and the depth of flow approaching the embankment less any roadway overtopping. 


\section{Scour Results}

Contraction scour:

Main channel

Live-bed scour

Clear-water scour

Depth to armoring

Left overbank

Right overbank

Local scour:

Abutment scour

Left abutment

Right abutment

Pier scour

Pier 1

Pier 2

Pier 3
Abutments:

Left abutment

Right abutment

Piers:

Pier 1

Pier 2

$\begin{array}{ccc}\text { 100-year } & \text { Incipient } \\ \text { discharge } & \text { discharge } & \begin{array}{c}\text { overtopping } \\ \text { discharge }\end{array}\end{array}$

(Scour depths in feet)

\begin{tabular}{|c|c|c|}
\hline -- & -- & -- \\
\hline 0.1 & 1.5 & 0.3 \\
\hline $13.2^{-}$ & $12.6^{-}$ & $19.4^{-}$ \\
\hline-- & $--^{-}$ & $--^{-}$ \\
\hline--- & -- & -- \\
\hline
\end{tabular}

6.57 .0

6.65 .6

5.7

6.0
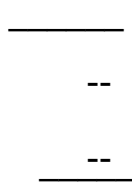

$--$
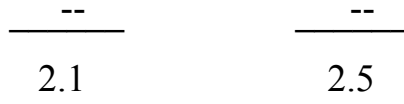

2.5

\section{Riprap Sizing}

100-year discharge

1.8

1.8
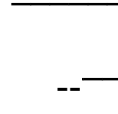

$-$
Incipient

500-year discharge ( $D_{50}$ in feet)

2.1
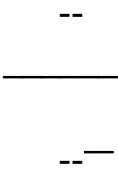

-- overtopping discharge

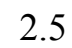




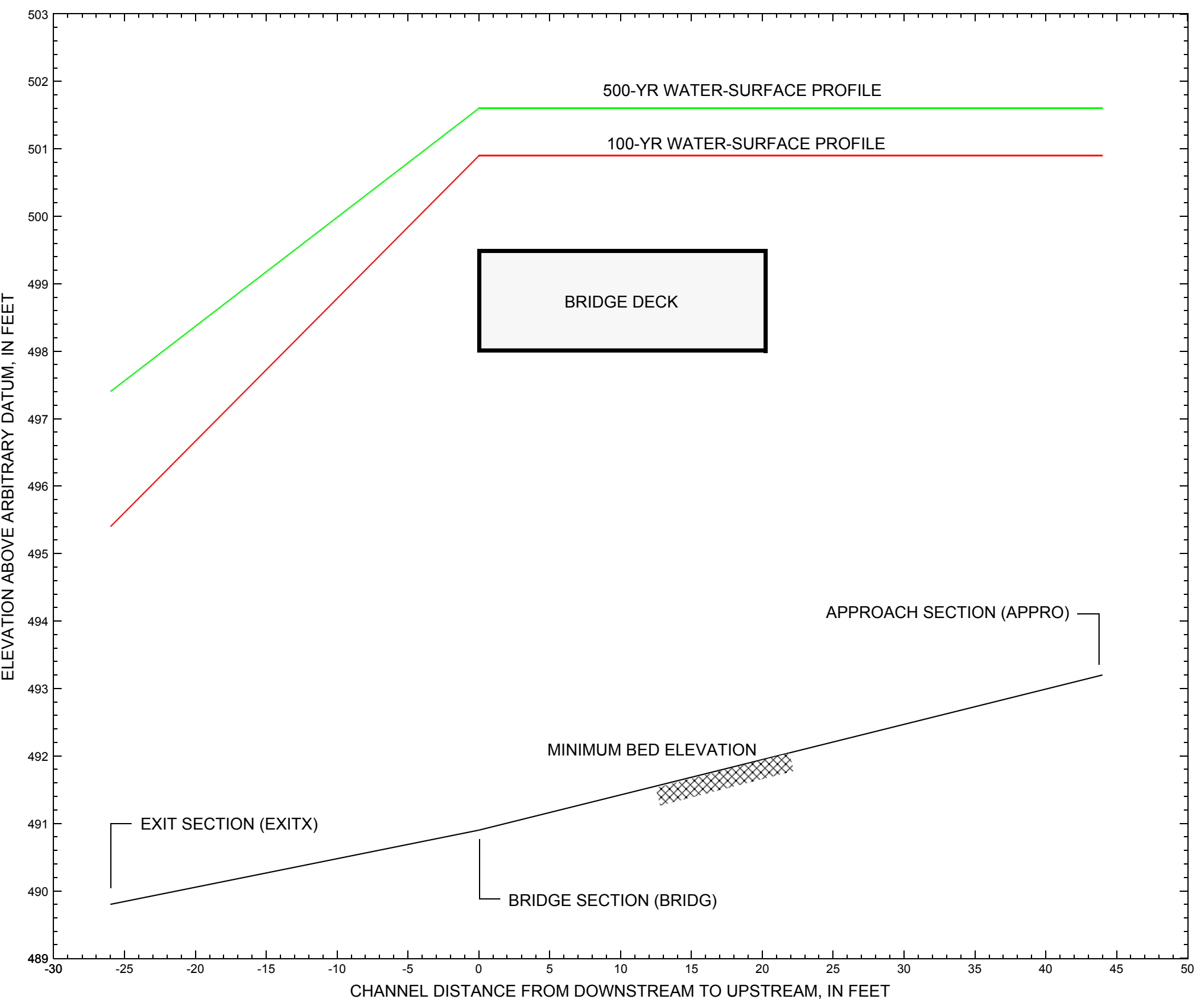

Figure 7. Water-surface profiles for the 100- and 500-yr discharges at structure ROCHTH00400025 on Town Highway 40, crossing Corporation Brook, Rochester, Vermont. 


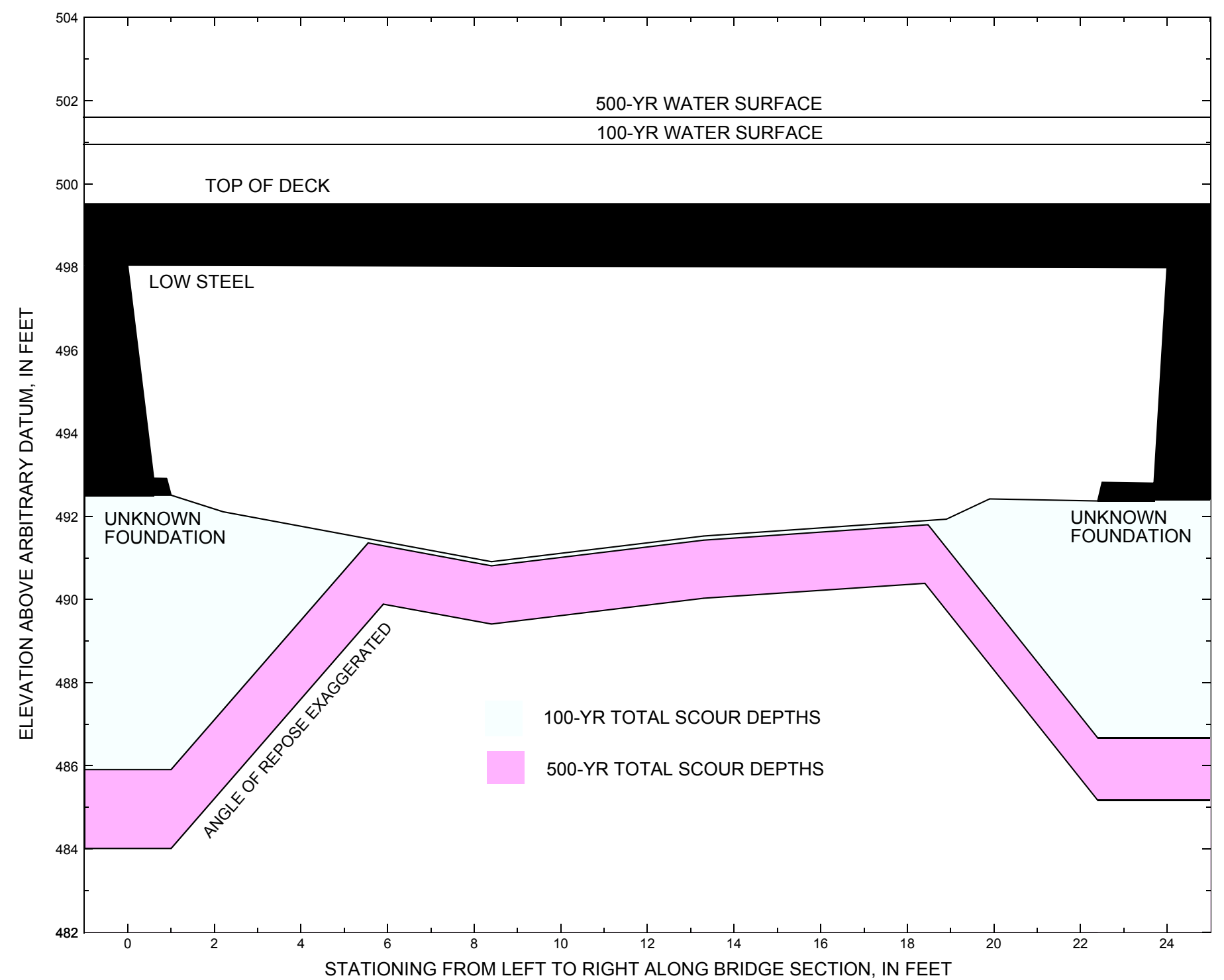

Figure 8. Scour elevations for the 100- and 500-yr discharges at structure ROCHTH00400025 on Town Highway 40, crossing Corporation Brook, Rochester, Vermont. 
Table 1. Remaining footing/pile depth at abutments for the 100-yr discharge at structure ROCHTH00400025 on Town Highway 40, crossing Corporation Brook, Rochester, Vermont.

[VTAOT, Vermont Agency of Transportation; --, no data]

\begin{tabular}{|c|c|c|c|c|c|c|c|c|c|c|c|}
\hline Description & Station $^{1}$ & $\begin{array}{l}\text { VTAOT } \\
\text { minimum } \\
\text { low-chord } \\
\text { elevation } \\
\text { (feet) }\end{array}$ & $\begin{array}{c}\text { Surveyed } \\
\text { minimum } \\
\text { low-chord } \\
\text { elevation } \\
\text { (feet) }\end{array}$ & $\begin{array}{c}\text { Bottom of } \\
\text { footing/pile } \\
\text { elevation }{ }^{2} \\
\text { (feet) }\end{array}$ & $\begin{array}{l}\text { Channel } \\
\text { elevation at } \\
\text { abutment/ } \\
\text { pier }^{2} \\
\text { (feet) }\end{array}$ & $\begin{array}{l}\text { Contraction } \\
\text { scour depth } \\
\text { (feet) }\end{array}$ & $\begin{array}{l}\text { Abutment } \\
\text { scour } \\
\text { depth } \\
\text { (feet) }\end{array}$ & $\begin{array}{l}\text { Pier } \\
\text { scour } \\
\text { depth } \\
\text { (feet) }\end{array}$ & $\begin{array}{l}\text { Depth of } \\
\text { total scour } \\
\text { (feet) }\end{array}$ & $\begin{array}{c}\text { Elevation of } \\
\text { scour }^{2} \\
\text { (feet) }\end{array}$ & $\begin{array}{c}\text { Remaining } \\
\text { footing/pile } \\
\text { depth } \\
\text { (feet) }\end{array}$ \\
\hline \multicolumn{12}{|c|}{100 -yr discharge is 1,680 cubic-feet per second } \\
\hline Left abutment & 0.0 & -- & 498.0 & -- & 492.5 & 0.1 & 6.5 & -- & 6.6 & 485.9 & -- \\
\hline Right abutment & 24.0 & -- & 498.0 & -- & 492.4 & 0.1 & 5.6 & -- & 5.7 & 486.7 & -- \\
\hline
\end{tabular}

1.Measured along the face of the most constricting side of the bridge.

2.Arbitrary datum for this study.

Table 2. Remaining footing/pile depth at abutments for the 500-yr discharge at structure ROCHTH00400025 on Town Highway 40, crossing Corporation Brook, Rochester, Vermont.

[VTAOT, Vermont Agency of Transportation; --, no data]

\begin{tabular}{|c|c|c|c|c|c|c|c|c|c|c|c|}
\hline Description & Station $^{1}$ & $\begin{array}{l}\text { VTAOT } \\
\text { minimum } \\
\text { low-chord } \\
\text { elevation } \\
\text { (feet) }\end{array}$ & $\begin{array}{c}\text { Surveyed } \\
\text { minimum } \\
\text { low-chord } \\
\text { elevation } \\
\text { (feet) }\end{array}$ & $\begin{array}{c}\text { Bottom of } \\
\text { footing/pile } \\
\text { elevation } \\
\text { (feet) }\end{array}$ & $\begin{array}{c}\text { Channel } \\
\text { elevation at } \\
\text { abutment/ } \\
\text { pier }^{2} \\
\text { (feet) }\end{array}$ & $\begin{array}{l}\text { Contraction } \\
\text { scour depth } \\
\text { (feet) }\end{array}$ & $\begin{array}{c}\text { Abutment } \\
\text { scour } \\
\text { depth } \\
\text { (feet) }\end{array}$ & $\begin{array}{l}\text { Pier } \\
\text { scour } \\
\text { depth } \\
\text { (feet) }\end{array}$ & $\begin{array}{l}\text { Depth of } \\
\text { total scour } \\
\text { (feet) }\end{array}$ & $\begin{array}{c}\text { Elevation of } \\
\text { scour }^{2} \\
\text { (feet) }\end{array}$ & $\begin{array}{c}\text { Remaining } \\
\text { footing/pile } \\
\text { depth } \\
\text { (feet) }\end{array}$ \\
\hline \multicolumn{12}{|c|}{500 -yr discharge is 2,400 cubic-feet per second } \\
\hline Left abutment & 0.0 & -- & 498.0 & -- & 492.5 & 1.5 & 7.0 & -- & 8.5 & 484.0 & -- \\
\hline Right abutment & 24.0 & -- & 498.0 & -- & 492.4 & 1.5 & 5.7 & -- & 7.2 & 485.2 & -- \\
\hline
\end{tabular}

1.Measured along the face of the most constricting side of the bridge.

2.Arbitrary datum for this study. 


\section{SELECTED REFERENCES}

Arcement, G.J., Jr., and Schneider, V.R., 1989, Guide for selecting Manning's roughness coefficients for natural channels and flood plains: U.S. Geological Survey Water-Supply Paper 2339, 38 p.

Barnes, H.H., Jr., 1967, Roughness characteristics of natural channels: U.S. Geological Survey Water-Supply Paper 1849,213 p.

Benson, M. A., 1962, Factors Influencing the Occurrence of Floods in a Humid Region of Diverse Terrain: U.S. Geological Survey WaterSupply Paper 1580-B, 64 p.

Brown, S.A. and Clyde, E.S., 1989, Design of riprap revetment: Federal Highway Administration Hydraulic Engineering Circular No. 11, Publication FHWA-IP-89-016, 156 p.

Federal Highway Administration, 1983, Runoff estimates for small watersheds and development of sound design: Federal Highway Administration Report FHWA-RD-77-158.

Federal Highway Administration, 1993, Stream Stability and Scour at Highway Bridges: Participant Workbook: Federal Highway Administration Report FHWA-HI-91-011.

Froehlich, D.C., 1989, Local scour at bridge abutments in Ports, M.A., ed., Hydraulic Engineering--Proceedings of the 1989 National Conference on Hydraulic Engineering: New York, American Society of Civil Engineers, p. 13-18.

Hayes, D.C.,1993, Site selection and collection of bridge-scour data in Delaware, Maryland, and Virginia: U.S. Geological Survey WaterResources Investigation Report 93-4017, 23 p.

Interagency Advisory Committee on Water Data, 1982, Guidelines for determining flood flow frequency: U.S. Geological Survey, Bulletin 17B of the Hydrology Subcommittee, 190 p.

Johnson, C.G. and Tasker, G.D.,1974, Progress report on flood magnitude and frequency of Vermont streams: U.S. Geological Survey OpenFile Report 74-130, 37 p.

Lagasse, P.F., Schall, J.D., Johnson, F., Richardson, E.V., Chang, F., 1995, Stream Stability at Highway Structures: Federal Highway Administration Hydraulic Engineering Circular No. 20, Publication FHWA-IP-90-014, 144 p.

Laursen, E.M., 1960, Scour at bridge crossings: Journal of the Hydraulics Division, American Society of Civil Engineers, v. 86, no. HY2, p. 39-53.

Potter, W. D., 1957a, Peak rates of runoff in the Adirondack, White Mountains, and Maine woods area, Bureau of Public Roads

Potter, W. D., 1957b, Peak rates of runoff in the New England Hill and Lowland area, Bureau of Public Roads

Richardson, E.V. and Davis, S.R., 1995, Evaluating scour at bridges: Federal Highway Administration Hydraulic Engineering Circular No. 18, Publication FHWA-IP-90-017, 204 p.

Richardson, E.V., Simons, D.B., and Julien, P.Y., 1990, Highways in the river environment: Federal Highway Administration Publication FHWA-HI-90-016.

Ritter, D.F., 1984, Process Geomorphology: W.C. Brown Co., Debuque, Iowa, 603 p.

Shearman, J.O., 1990, User's manual for WSPRO--a computer model for water surface profile computations: Federal Highway Administration Publication FHWA-IP-89-027, 187 p.

Shearman, J.O., Kirby, W.H., Schneider, V.R., and Flippo, H.N., 1986, Bridge waterways analysis model; research report: Federal Highway Administration Publication FHWA-RD-86-108, 112 p.

Talbot, A.N., 1887, The determination of water-way for bridges and culverts.

U.S. Geological Survey, 1970, Rochester, Vermont 7.5 Minute Series quadrangle map: U.S. Geological Survey Topographic Maps, Scale 1:24,000. 


\section{APPENDIX A: \\ WSPRO INPUT FILE}




\section{WSPRO INPUT FILE}

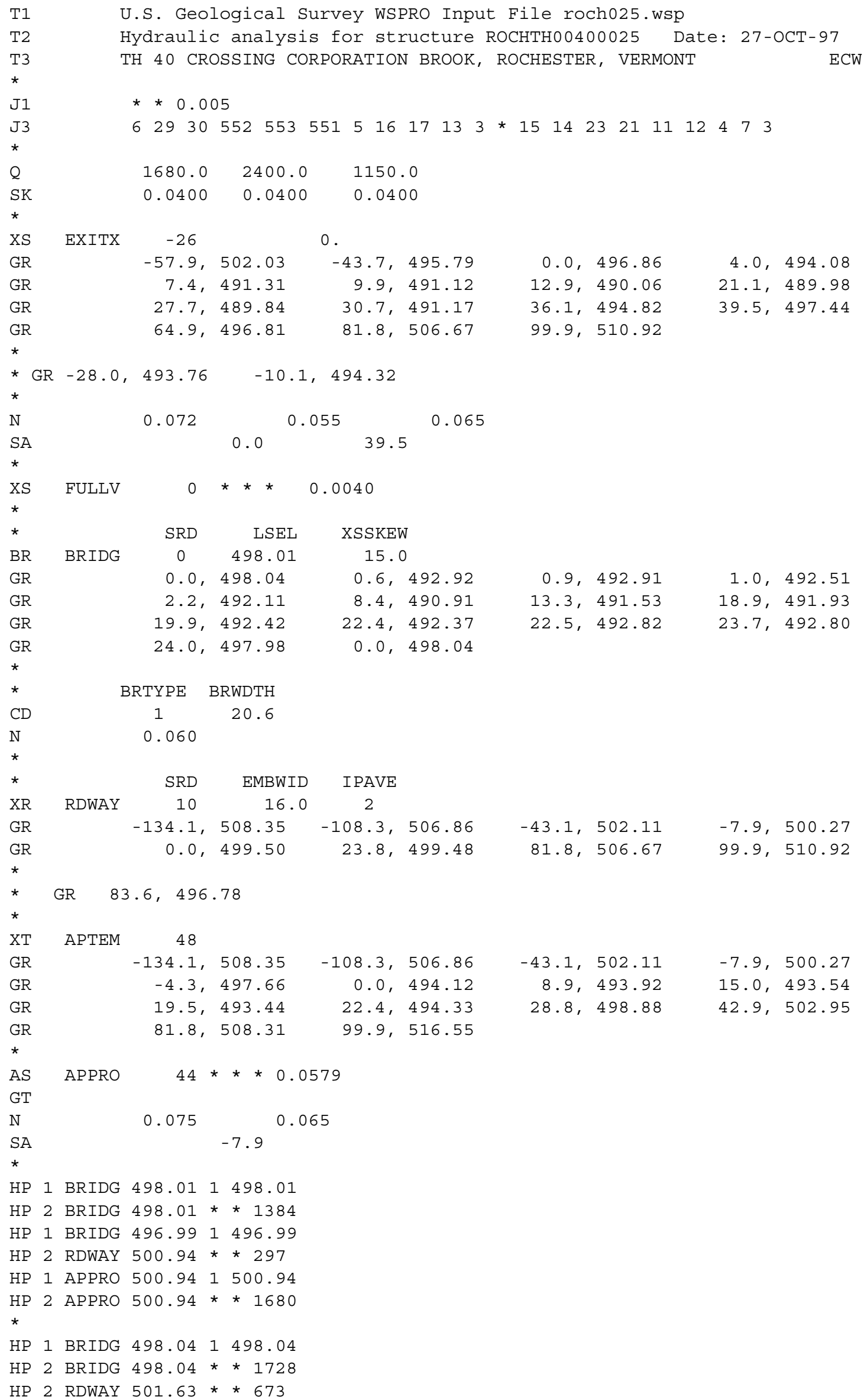




\section{APPENDIX B: \\ WSPRO OUTPUT FILE}




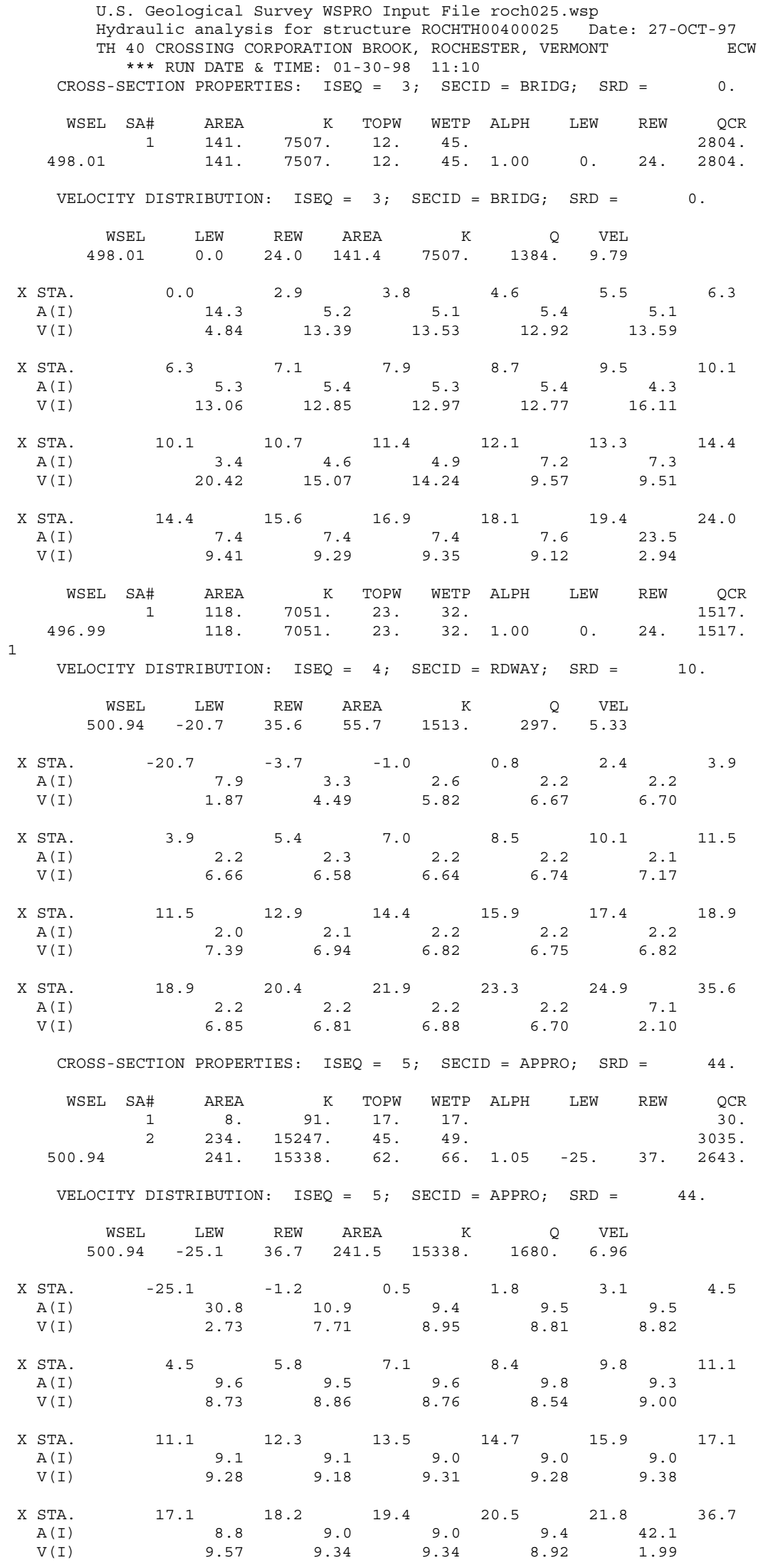


WSPRO OUTPUT FILE (continued)

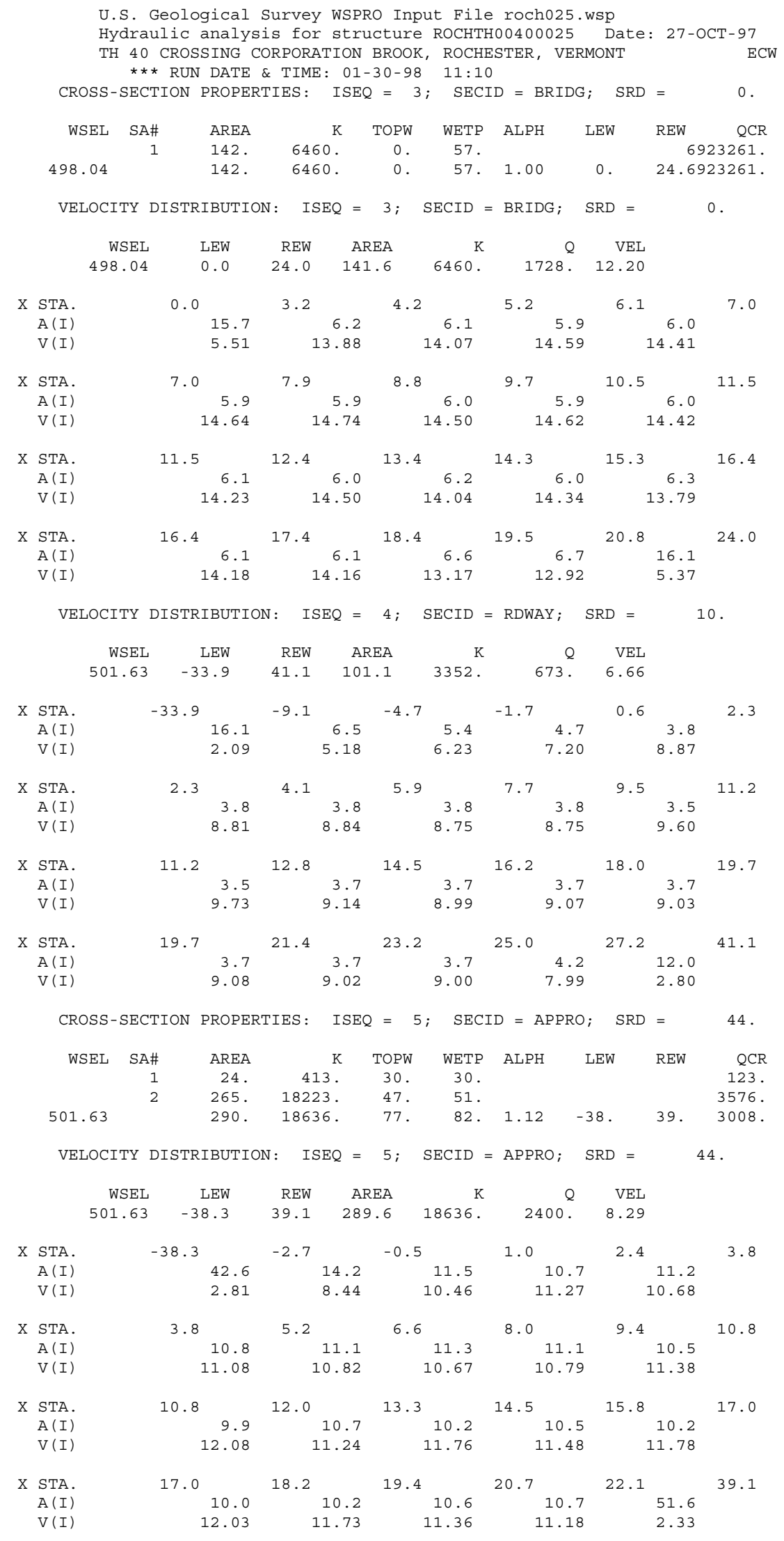


WSPRO OUTPUT FILE (continued)

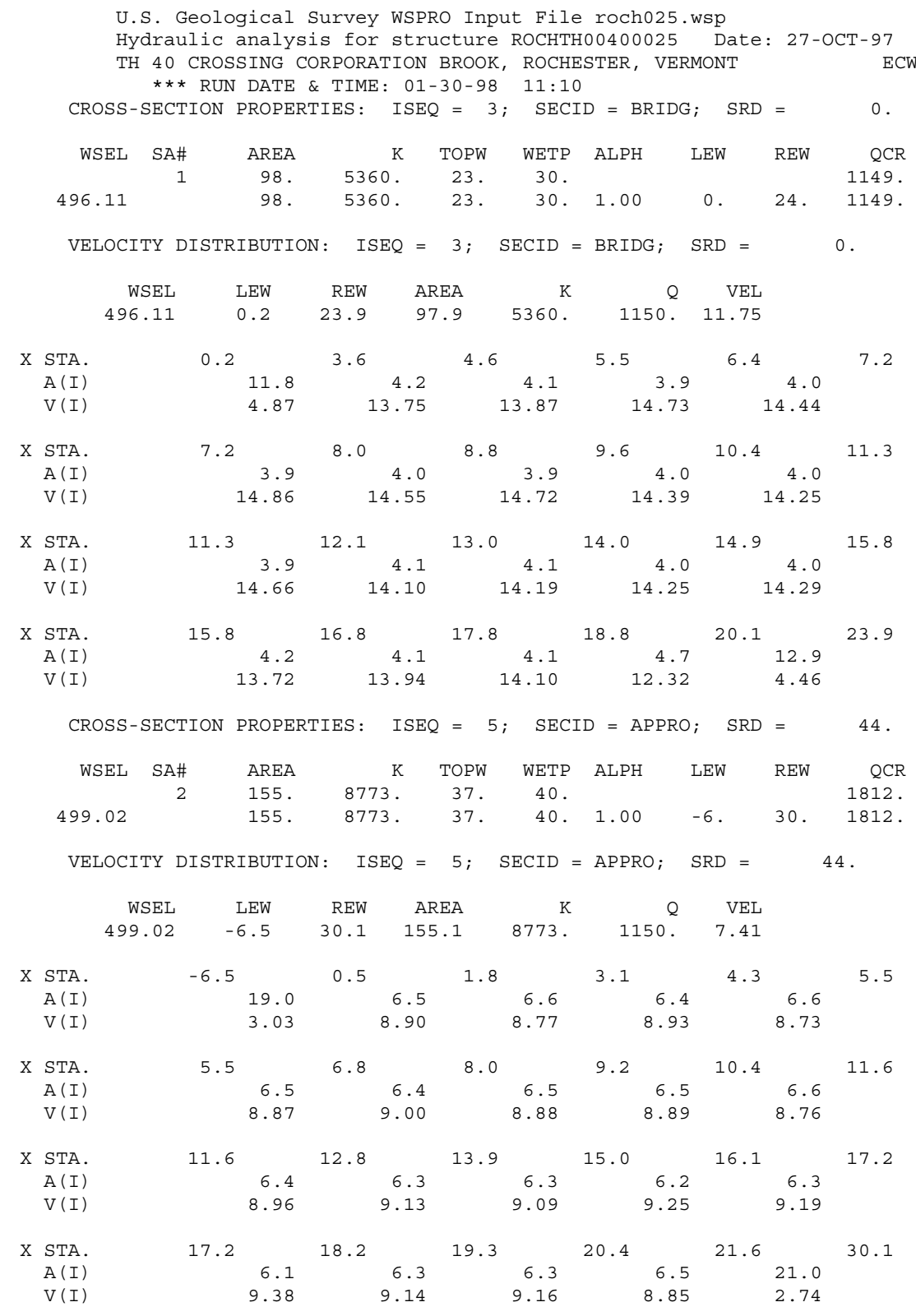


WSPRO OUTPUT FILE (continued)

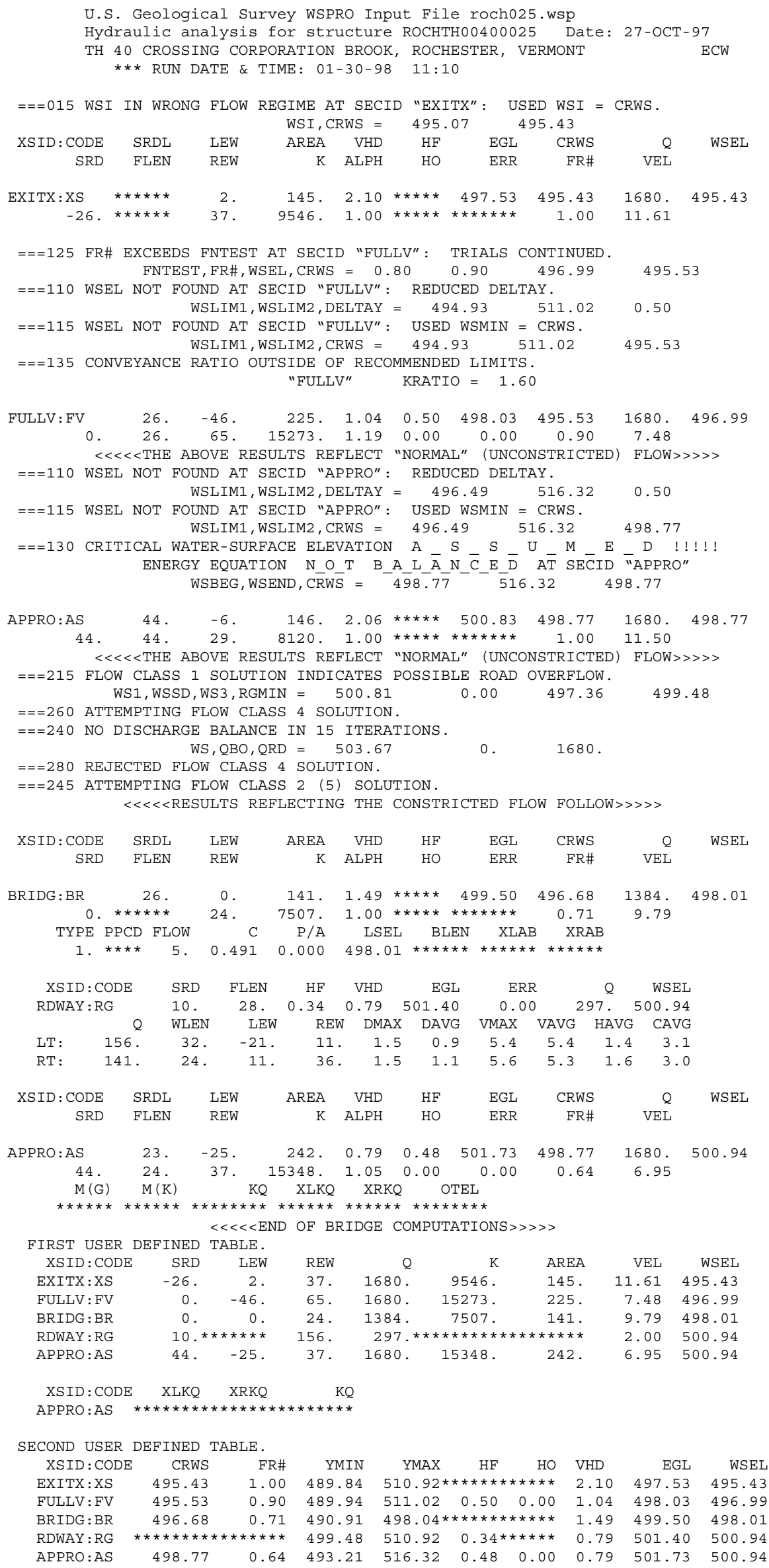


WSPRO OUTPUT FILE (continued)

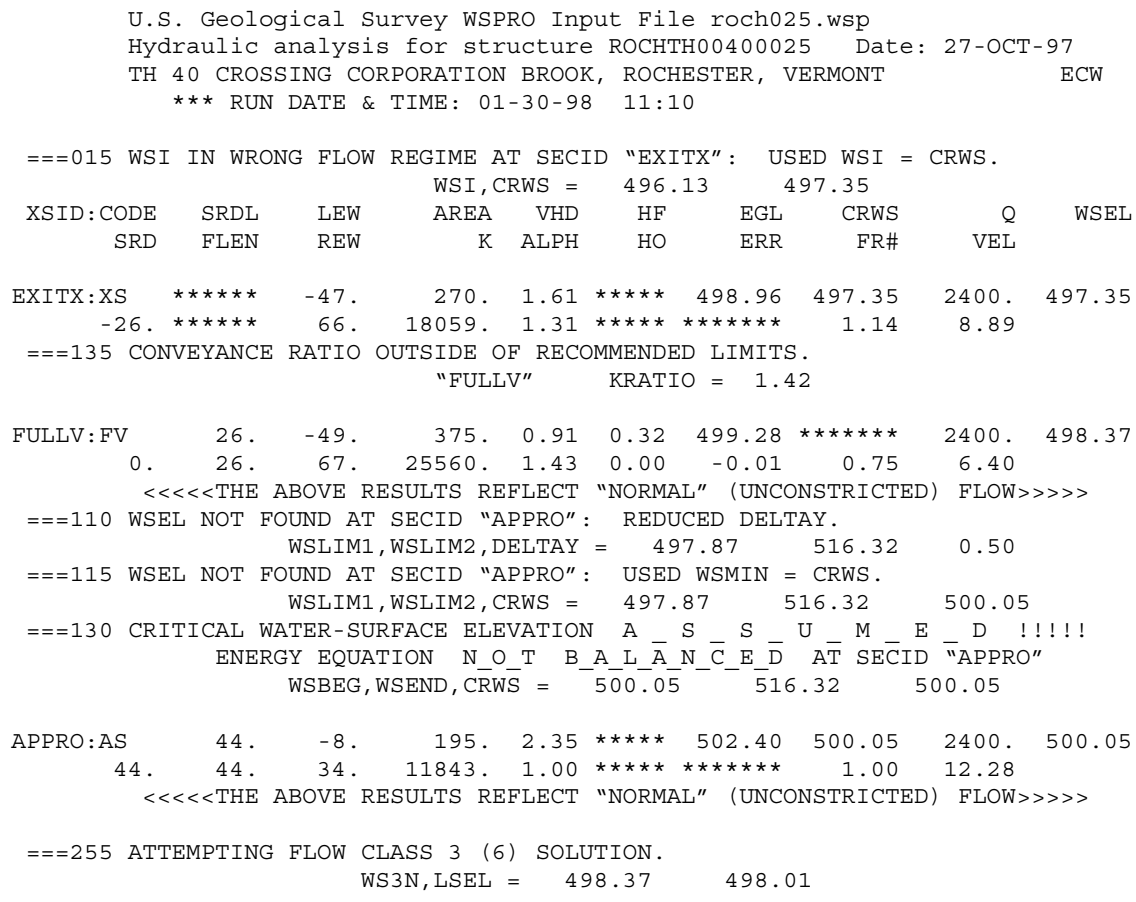


WSPRO OUTPUT FILE (continued)

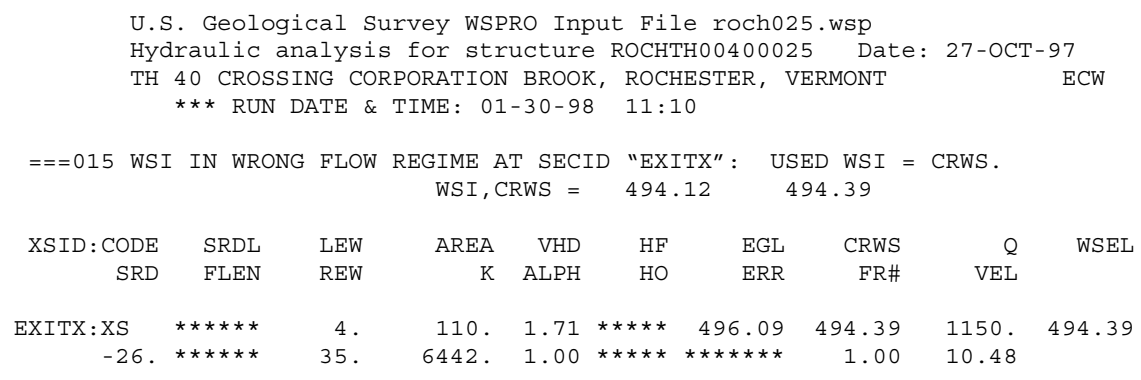

$==135$ CONVEYANCE RATIO OUTSIDE OF RECOMMENDED LIMITS.

"FULLV" KRATIO $=1.56$

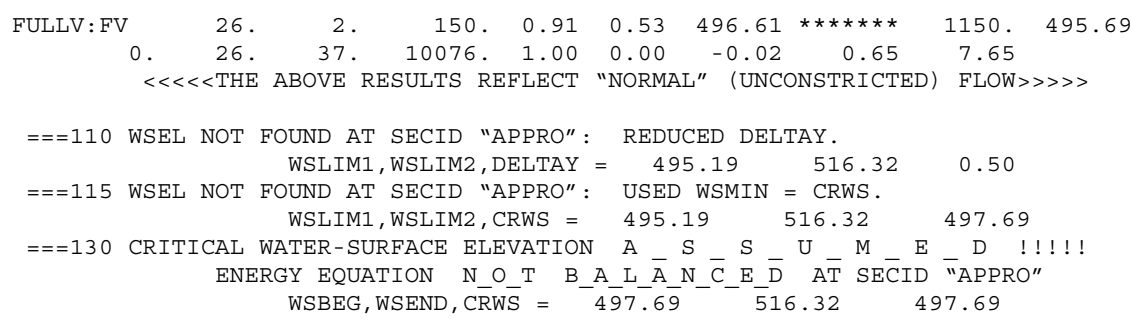




\section{APPENDIX C:}

\section{BED-MATERIAL PARTICLE-SIZE DISTRIBUTION}




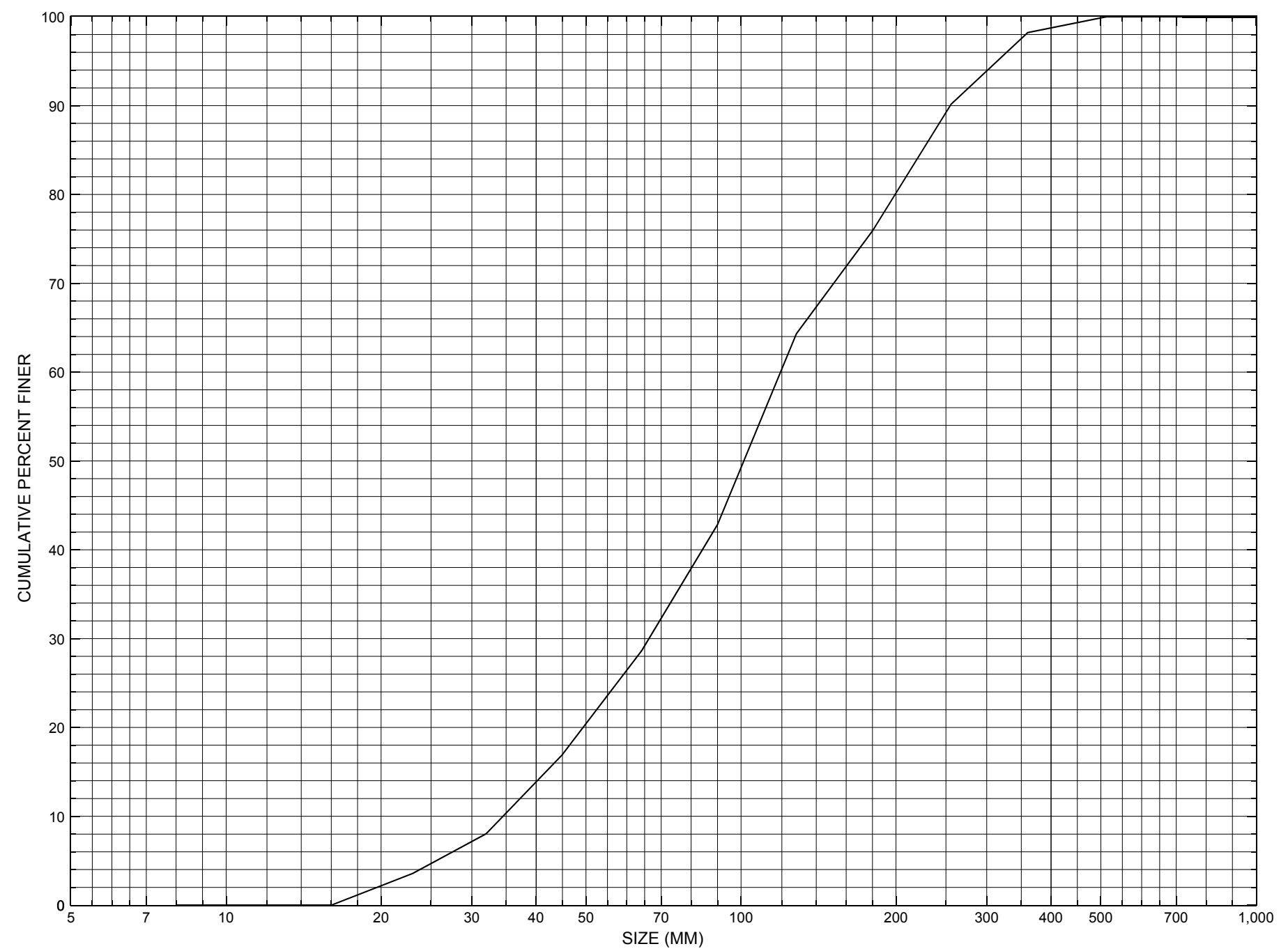

Appendix C. Bed material particle-size distribution for a pebble count in the channel approach of structure ROCHTH00400025, in Rochester, Vermont. 


\section{APPENDIX D: \\ HISTORICAL DATA FORM}




\section{Structure Number ROCHTH00400025}

\section{General Location Descriptive}

Data collected by (First Initial, Full last name) $\mathbf{E}$. BOEHMLER

Date $(M M / D D / Y Y) \_\mathbf{0 3} / \underline{22} / \underline{95}$

Highway District Number (I - 2; nn) $\mathbf{0 4}$

Town (FIPS place code; I - 4; nnnnn) $\mathbf{6 0 1 0 0}$

Waterway (I - 6) CORPORATION BROOK

Route Number TH040

Topographic Map Rochester

Latitude (I - 16; nnnn.n) $\mathbf{4 3 5 0 7}$
County (FIPS county code; I - 3; nnn)

Mile marker (I - 11; nnn.nnn) $\mathbf{0 0 0 0 0 0}$

Road Name (I - 7): -

Vicinity (I - 9) 0.3 MI JCT TH $40+$ VT 73

Hydrologic Unit Code: $\mathbf{0 1 0 8 0 1 0 5}$

Longitude (i - 17; nnnnn.n) $\mathbf{7 2 5 1 0}$

\section{Select Federal Inventory Codes}

FHWA Structure Number $(I$ - 8) 10141500251415

Maintenance responsibility $(I-21 ; n n) \quad \mathbf{0 3}$

Year built (I - 27; YYYY) 1930

Average daily traffic, ADT (I - 29; nnnnnn) 000100

Year of ADT (I - 30; YY) $\mathbf{9 4}$

Opening skew to Roadway $(I-34 ; n n) \quad 15$

Operational status $(I-41 ; X) \quad \mathbf{A}$

Structure type (I - 43; nnn) $\mathbf{3 0 2}$

Approach span structure type (I - 44; nnn) $\mathbf{0 0 0}$

Number of spans (I - 45; nnn) $\underline{\mathbf{0 0 1}}$

Number of approach spans (I - 46; nnnn) $\mathbf{0 0 0 0}$

Comments:

The structural inspection report of 7/2/93 indicates the structure is a single span, steel stringer type bridge with a timber deck. The report indicates the abutments apparently are concrete faced, "laid-up" stone walls. There are some voids reported in the concrete facing along the bottom at the upstream end of the right abutment wall. The abutment walls have concrete footings. These footings are noted as not appearing to be undermined or settled. The waterway makes a slight bend into the crossing, reportedly. The report notes that the streambed consists of mainly stone and gravel with some randomly distributed boulders. There is stonefill reported as native cobbles and boulders on the abutments. (Continued, page 33) 


\section{Bridge Hydrologic Data}

Is there hydrologic data available? $\underline{\mathbf{N}}$ if No, type ctrl-n $h \quad$ VTAOT Drainage area $\left(m i^{2}\right)$ : -

Terrain character:

Stream character \& type: -

Streambed material:

Discharge Data (cfs):

$$
\begin{aligned}
& Q_{2.33}- \\
& Q_{50}-
\end{aligned}
$$

Record flood date $(M M / D D / Y Y)$ :

Estimated Discharge (cfs): Ice conditions (Heavy, Moderate, Light) : -

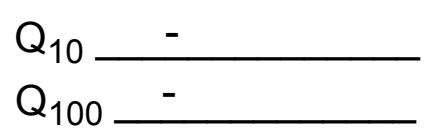

$$
\begin{aligned}
& Q_{25}- \\
& Q_{500}-
\end{aligned}
$$

Water surface elevation $(f t):-$

The stage increases to maximum highwater elevation (Rapidly, Not rapidly):

The stream response is (Flashy, Not flashy):

Describe any significant site conditions upstream or downstream that may influence the stream's stage: -

Watershed storage area (in percent): _ _ \%

The watershed storage area is: - (1-mainly at the headwaters; 2- uniformly distributed; 3-immediatly upstream oi the site)

Water Surface Elevation Estimates for Existing Structure:

\begin{tabular}{|l|l|l|l|l|l|}
\hline Peak discharge frequency & $Q_{2.33}$ & $Q_{10}$ & $Q_{25}$ & $Q_{50}$ & $Q_{100}$ \\
Water surface elevation (ft)) & - & - & - & - & - \\
Velocity (ft/sec) & - & - & - & - & - \\
\hline
\end{tabular}

Long term stream bed changes: -

Is the roadway overtopped below the $\mathrm{Q}_{100}$ ? (Yes, No, Unknown): $\mathbf{U}$ Frequency: Relief Elevation (ft): Discharge over roadway at $Q_{100}\left(f^{3} / \mathrm{sec}\right)$ :

Are there other structures nearby? (Yes, No, Unknown): $\underline{\mathbf{U}}$ Upstream distance (miles): Town: If No or Unknown, type ctrl-n os Highway No. : Structure No. : Year Built:

Clear span (ft): Clear Height $(f t)$ : Full Waterway $\left(f^{2}\right)$ : 
Downstream distance (miles): Town: Year Built:

Highway No. : Structure No. : Structure Type:

Clear span (ft): Clear Height $(f t)$ : Full Waterway $\left(f t^{2}\right)$ :

Comments:

Only minor channel scour is noted. Bank erosion is noted as typical for a mountain stream. Debris is noted as not evident.

\section{USGS Watershed Data}

Watershed Hydrographic Data

Drainage area $(D A)$

Watershed storage (ST)

Bridge site elevation

Main channel length 0 $\mathrm{mi}^{2}$ 1010 3.47 $10 \%$ channel length elevation 1110
Lake/pond/swamp area $\mathbf{0}$ $\mathrm{mi}^{2}$ $\%$

Main channel slope $(S) \quad \mathbf{5 4 1 . 7 9} \mathrm{ft} / \mathrm{mi}$

Watershed Precipitation Data

Average site precipitation in Average headwater precipitation in

Maximum 2yr-24hr precipitation event $(124,2)$ in

Average seasonal snowfall (Sn) $\mathrm{ft}$ 


\section{Bridge Plan Data}

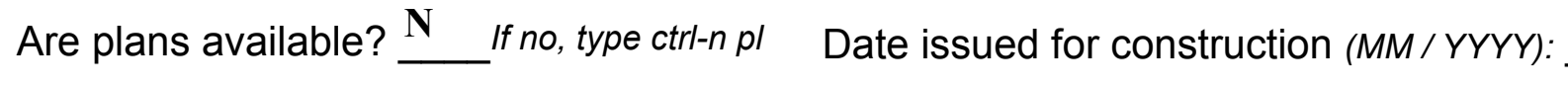

Project Number

Minimum channel bed elevation:

Low superstructure elevation: USLAB DSLAB USRAB DSRAB Benchmark location description:

NO BENCHMARK INFORMATION

Reference Point (MSL, Arbitrary, Other): Datum (NAD27, NAD83, Other):

Foundation Type: 4

If 1: Footing Thickness

If 2: Pile Type: (1-Wood; 2-Steel or metal; 3-Concrete)

If 3 : Footing bottom elevation:

Is boring information available? $\mathbf{N}$ If no, type ctrl-n bi Number of borings taken:

Foundation Material Type: $\mathbf{3}$ (1-regolith, 2-bedrock, 3-unknown)

Briefly describe material at foundation bottom elevation or around piles:

NO FOUNDATION MATERIAL INFORMATION

Comments:

NO PLANS. 


\section{Cross-sectional Data}

Is cross-sectional data available? $\mathbf{N}$ If no, type ctrl-n xs

Source (FEMA, VTAOT, Other)? -

Comments:

\section{NO CROSS SECTION INFORMATION}

\begin{tabular}{|l|l|l|l|l|l|l|l|l|l|l|l|}
\hline Station & - & - & - & - & - & - & - & - & - & - & - \\
\hline Feature & - & - & - & - & - & - & - & - & - & - & - \\
\hline $\begin{array}{l}\text { Low chord } \\
\text { elevation }\end{array}$ & - & - & - & - & - & - & - & - & - & - & - \\
\hline $\begin{array}{l}\text { Bed } \\
\text { elevation }\end{array}$ & - & - & - & - & - & - & - & - & - & - & - \\
\hline $\begin{array}{l}\text { Low chord } \\
\text { to bed }\end{array}$ & - & - & - & - & - & - & - & - & - & - & - \\
\hline Station & - & - & - & - & - & - & - & - & - & - & - \\
\hline Feature & - & - & - & - & - & - & - & - & - & - & - \\
\hline $\begin{array}{l}\text { Low chord } \\
\text { elevation }\end{array}$ & - & - & - & - & - & - & - & - & - & - & - \\
\hline $\begin{array}{l}\text { Bed } \\
\text { elevation }\end{array}$ & - & - & - & - & - & - & - & - & - & - & - \\
\hline $\begin{array}{l}\text { Low chord } \\
\text { to bed }\end{array}$ & - & - & - & - & - & - & - & - & - & - & - \\
\hline
\end{tabular}

Source (FEMA, VTAOT, Other)?

Comments: NO CROSS SECTION INFORMATION

\begin{tabular}{|l|l|l|l|l|l|l|l|l|l|l|l|}
\hline Station & - & - & - & - & - & - & - & - & - & - & - \\
\hline Feature & - & - & - & - & - & - & - & - & - & - & - \\
\hline $\begin{array}{l}\text { Low chord } \\
\text { elevation }\end{array}$ & - & - & - & - & - & - & - & - & - & - & - \\
\hline $\begin{array}{l}\text { Bed } \\
\text { elevation }\end{array}$ & - & - & - & - & - & - & - & - & - & - & - \\
\hline $\begin{array}{l}\text { Low chord } \\
\text { to bed }\end{array}$ & - & - & - & - & - & - & - & - & - & - & - \\
\hline Station & - & - & - & - & - & - & - & - & - & - & - \\
\hline Feature & - & - & - & - & - & - & - & - & - & - & - \\
\hline $\begin{array}{l}\text { Low chord } \\
\text { elevation }\end{array}$ & - & - & - & - & - & - & - & - & - & - & - \\
\hline $\begin{array}{l}\text { Bed } \\
\text { elevation }\end{array}$ & - & - & - & - & - & - & - & - & - & - & - \\
\hline $\begin{array}{l}\text { Low chord } \\
\text { to bed }\end{array}$ & - & - & - & - & - & - & - & - & - & - & - \\
\hline
\end{tabular}




\section{APPENDIX E: \\ LEVEL I DATA FORM}


U. S. Geological Survey

Bridge Field Data Collection and Processing Form

Qa/Qc Check by: $\mathbf{R B}$ Date: $09 / 30 / 96$

\section{Structure Number}

ROCHTH00400025

Computerized by: $\underline{\mathbf{R B}}$ Date: $09 / 30 / 96$

Reviewd by: $\quad$ EW Date: $\underline{\mathbf{2} / \mathbf{1 0} / 98}$

\section{A. General Location Descriptive}

1. Data collected by (First Initial, Full last name) M. WEBER

Date $(M M / D D / Y Y) \mathbf{0 4} / \underline{12} / \underline{1995}$

2. Highway District Number 04

Mile marker 0000

County WINDSOR (027)

Town ROCHESTER (60100)

Waterway $(l$ - 6) CORPORATION BROOK

Route Number TH040

Road Name CORPORATION ROAD

Hydrologic Unit Code: $\mathbf{0 1 0 8 0 1 0 5}$

3. Descriptive comments:

Located 0.3 miles from the junction of TH 40 and VT 73.

\section{B. Bridge Deck Observations}
4. Surface cover... LBUS 6
RBUS 6
LBDS 6
RBDS 5
Overall 6

(2b us,ds,lb,rb: 1- Urban; 2- Suburban; 3- Row crops; 4- Pasture; 5- Shrub- and brushland; 6- Forest; 7- Wetland)
5. Ambient water surface... US 2
UB 2
DS 2
(1- pool; 2- riffle)

6. Bridge structure type 1 (1- single span; 2- multiple span; 3- single arch; 4- multiple arch; 5-cylindrical culvert; 6- box culvert; or 7- other)
7. Bridge length $\mathbf{3 1}$
(feet)
Span length 26
(feet)
Bridge width 16 (feet)

\section{Road approach to bridge:}
8. LB 2 RB 1
( 0 even, 1- lower, 2- higher)
9. LB_2
RB $\underline{2}$
(1-Paved, 2- Not paved)

10. Embankment slope (run / rise in feet / foot)

US left

US right

\begin{tabular}{|c|c|c|c|}
\hline \multicolumn{2}{|c|}{ Protection } & \multirow{2}{*}{ 13.Erosion } & 14.Severity \\
\hline 11.Type & 12.Cond. & - & $\underline{\mathbf{1}}$ \\
\hline $\mathbf{2}$ & $\mathbf{1}$ & $\mathbf{2}$ & - \\
$\mathbf{2}$ & $\mathbf{1}$ & $\mathbf{0}$ & - \\
$\mathbf{3}$ & $\mathbf{1}$ & $\mathbf{0}$ & - \\
\hline $\mathbf{2}$ & $\mathbf{1}$ & $\mathbf{0}$ & - \\
\hline
\end{tabular}

Bank protection types: 0- none; 1- < 12 inches,

2- < 36 inches; 3- < 48 inches;

4- < 60 inches; 5- wall / artificial levee

Bank protection conditions: 1- good; 2- slumped;

3- eroded; 4- failed

Erosion: 0 - none; 1- channel erosion; 2 -

road wash; 3- both; 4- other

Erosion Severity: 0 - none; 1- slight; 2- moderate; 3- severe

\section{Channel approach to bridge (BF):}

15. Angle of approach: 0

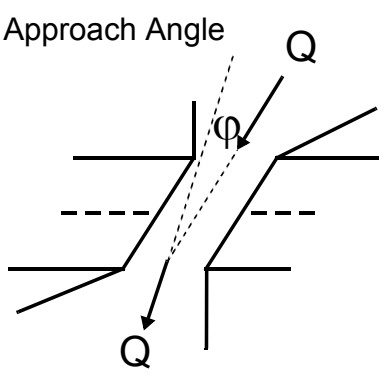

17. Channel impact zone 1 :

Where? RB (LB, RB)

Range? 30 feet US

Channel impact zone 2:

Where? $(L B, R B)$

Range? - $\quad$ feet -

(US, UB, DS) to Impact Severity: 0- none to very slight; 1- Slight; 2- Moderate; 3- Severe feet -

16. Bridge skew: 15 Bridge Skew Angle

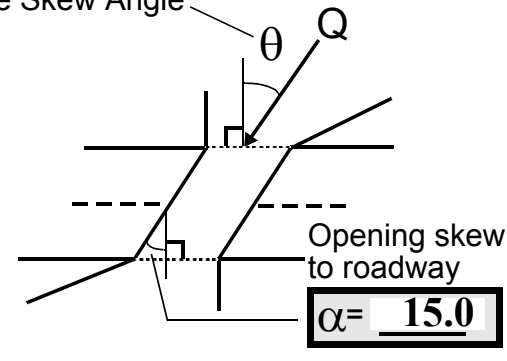

\section{Exist? $\mathbf{Y}(Y$ or $N)$}

Severity $\mathbf{0}$

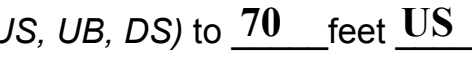

Exist? $\mathbf{N}(Y$ or $N)$

Severity - 
18. Bridge Type: $\mathbf{1 b}$

1a- Vertical abutments with wingwalls

$1 \mathrm{~b}$ - Vertical abutments without wingwalls

2- Vertical abutments and wingwalls, sloping embankment Wingwalls parallel to abut. face

3- Spill through abutments

4- Sloping embankment, vertical wingwalls and abutments

Wingwall angle less than $90^{\circ}$.

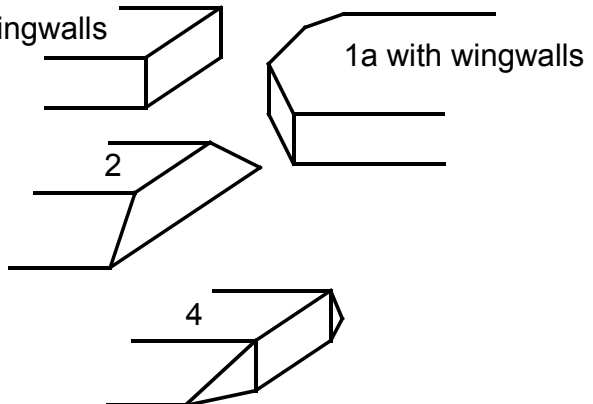

19. Bridge Deck Comments (surface cover variations, measured bridge and span lengths, bridge type variations, approach overflow width, etc.)

7. Values are from the VTAOT files. Measured bridge length is $32.5 \mathrm{ft}$, span length is $\mathbf{2 4 . 5} \mathrm{ft}$ and the bridge width is $16 \mathrm{ft}$. Lengths were measured at the downstream bridge face.

4. A few houses are visible from the deck but the predominant surface cover is forest. On the downstream right bank there is a clearing along with a dirt road and trees along the immediate bank.

11. The road approach protection is native channel material.

13. There is a small pool on the upstream left bank from road wash.

\section{Upstream Channel Assessment}

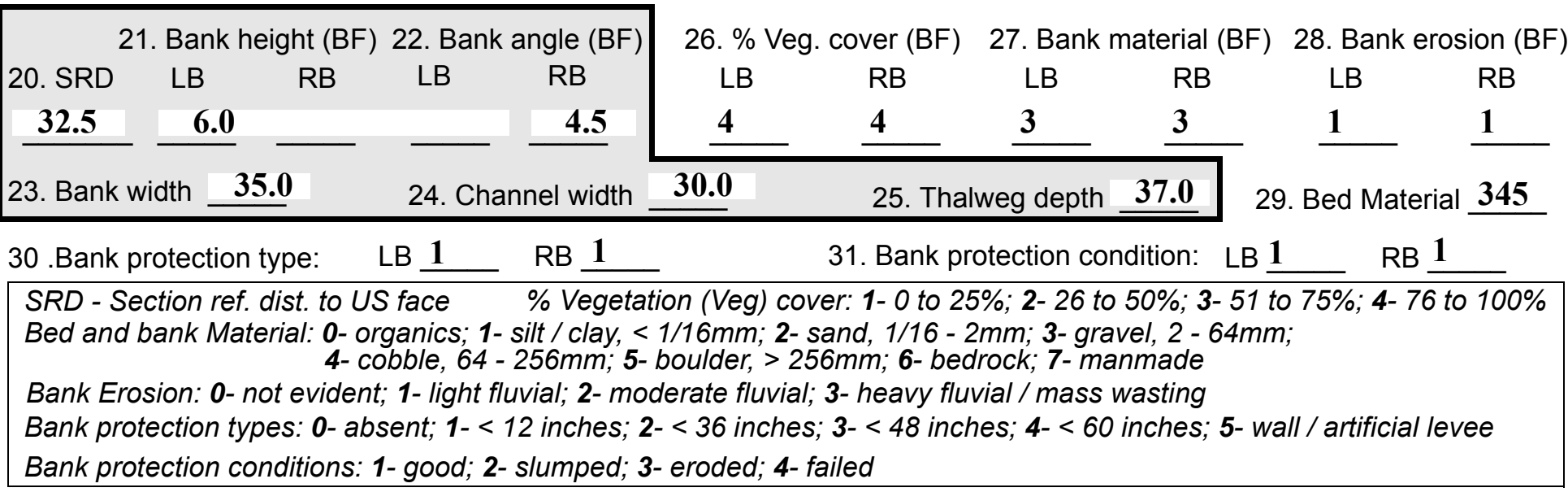

32. Comments (bank material variation, minor inflows, protection extent, etc.):

27. Bank material is gravel, sand, cobbles and boulders.

29. Bed material is gravel, cobbles and boulders.

30. Natural streambed fill is on both banks from $0 \mathrm{ft}$ US to $150 \mathrm{ft}$ US.

The upstream left bank has a wide shelf that is marshy in some places.

There is a National Forest Service survey monument $120 \mathrm{ft}$ US and $25 \mathrm{ft}$ from the right edge of water on the right bank. 
33.Point/Side bar present? $\mathbf{N}(Y$ or $N$. if $N$ type ctrl-n pb)34. Mid-bar distance: -

35. Mid-bar width:

36. Point bar extent: feet (US, UB) to feet (US, UB, DS) positioned $\%$ LB to $\% \mathrm{RB}$

37. Material: -

38. Point or side bar comments (Circle Point or Side; Note additional bars, material variation, status, etc.):

NO POINT BARS

39. Is a cut-bank present? $\underline{\mathbf{N}}$ (Y or if $\mathrm{N}$ type ctrl-n cb)

40. Where? (LB or $R B)$

41. Mid-bank distance: -

42. Cut bank extent: feet (US, UB) to feet (US, UB, DS)

43. Bank damage: (1- eroded and/or creep; 2- slip failure; 3- block failure)

44. Cut bank comments (eg. additional cut banks, protection condition, etc.):

NO CUT BANKS

45. Is channel scour present? $\mathbf{N}$ ( $Y$ or if $N$ type ctrl-n cs)

47. Scour dimensions: Length Width Depth : 46. Mid-scour distance: -

48. Scour comments (eg. additional scour areas, local scouring process, etc.):

NO CHANNEL SCOUR

49. Are there major confluences? $\mathbf{N}$

51. Confluence 1: Distance Confluence 2: Distance 52. Enters on Enters on 54. Confluence comments (eg. confluence name):

\section{NO MAJOR CONFLUENCES}

50. How many? -

53. Type(1-perennial; 2- ephemeral)

Type (1-perennial; 2-ephemeral)

\section{Under Bridge Channel Assessment}

55. Channel restraint (BF)? LB 2

\begin{tabular}{|c|c|}
\hline 56. Height (BF) & 57 Angle (BF) \\
\hline LB $\quad$ RB & $\mathrm{RB}$ \\
\hline 22.5 & 1.0 \\
\hline
\end{tabular}

58. Bank width (BF) (1- natural bank; 2- abutment; 3- artificial levee)

Bed and bank Material: 0- organics; 1- silt / clay, < 1/16mm; 2- sand, 1/16 - 2mm; 3- gravel, 2 - 64mm; 4- cobble, 64 - 256mm; 5- boulder, > 256mm; 6- bedrock; 7- manmade

Bank Erosion: 0- not evident; 1- light fluvial; 2- moderate fluvial; 3- heavy fluvial / mass wasting

64. Comments (bank material variation, minor inflows, protection extent, etc.):

34

63. Bed material is mostly gravel and cobbles under the bridge, though there is a boulder riffle at the downstream bridge face. 
65. Debris and Ice Is there debris accumulation?

67. Debris Potential 1 (1- Low; 2- Moderate; 3- High)

69. Is there evidence of ice build-up? 2

70. Debris and Ice Comments:

1

65. There are some branches and logs caught on the banks upstream and downstream.

68. Capture efficiency is moderate because at bank full the channel width under the bridge is about $75 \%$ of the width at $100 \mathrm{ft}$ US and there is low deck clearance. There is also a high stream slope.

\begin{tabular}{|l|c|c|c|c|c|c|c|c|}
\hline Abutments & $\begin{array}{c}\text { 71. Attack } \\
\angle \text { (BF) }\end{array}$ & $\begin{array}{c}\text { 72. Slope } \angle \\
\text { (Qmax) }\end{array}$ & $\begin{array}{c}\text { 73. Toe } \\
\text { loc. (BF) }\end{array}$ & $\begin{array}{c}\text { 74. Scour } \\
\text { Condition }\end{array}$ & $\begin{array}{c}75 . \text { Scour } \\
\text { depth }\end{array}$ & $\begin{array}{c}\text { 76. Exposure } \\
\text { depth }\end{array}$ & 77. Material & 78. Length \\
\hline LABUT & & - & $\mathbf{9 0}$ & $\mathbf{0}$ & $\mathbf{2}$ & $\mathbf{0}$ & $\mathbf{1}$ & $\mathbf{9 0 . 0}$ \\
\hline RABUT & $\mathbf{1}$ & - & $\mathbf{9 0}$ & & & $\mathbf{0}$ & $\mathbf{2}$ & $\mathbf{2 3 . 0}$ \\
\hline
\end{tabular}

Pushed: $L B$ or RB

Toe Location (Loc.): 0- even, 1- set back, 2- protrudes

Scour cond.: 0- not evident; 1- evident (comment); 2- footing exposed; 3-undermined footing; 4- piling exposed; 5- settled; 6- failed

Materials: 1- Concrete; 2- Stone masonry or drywall; 3- steel or metal; 4- wood

79. Abutment comments (eg. undermined penetration, unusual scour processes, debris, etc.):

0

2

1

The abutments are concrete faced, "laid-up" stone walls. At the downstream end of the right abutment footing, a wooden concrete form is visible. The maximum exposure depths are at the downstream end of the right abutment and at the upstream end of the left abutment. The footings are exposed the entire base length of both abutments.

80. Wingwalls:

$$
\text { Exist? Material? } \begin{gathered}
\text { Scour } \\
\text { Condition? }
\end{gathered} \text { depth? } \begin{array}{lll}
81 . & \\
\text { depth? } & \text { Angle? Length? }
\end{array}
$$

USLWW:

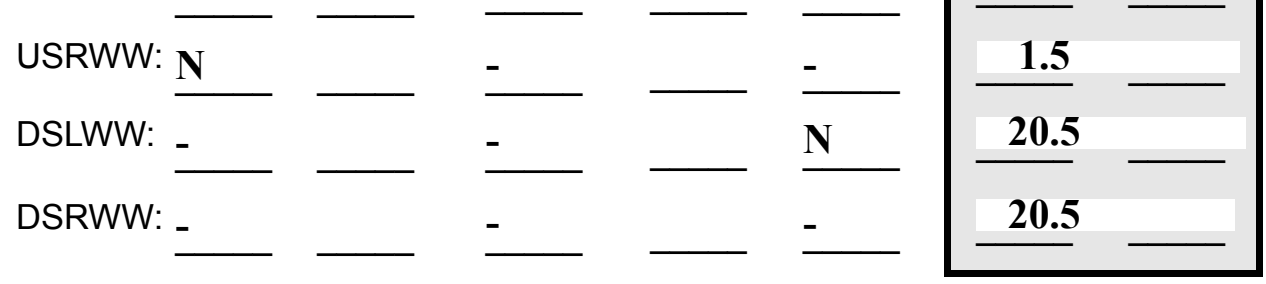

Wingwall materials: 1- Concrete; 2- Stone masonry or drywall; 3- steel or metal; 4- wood

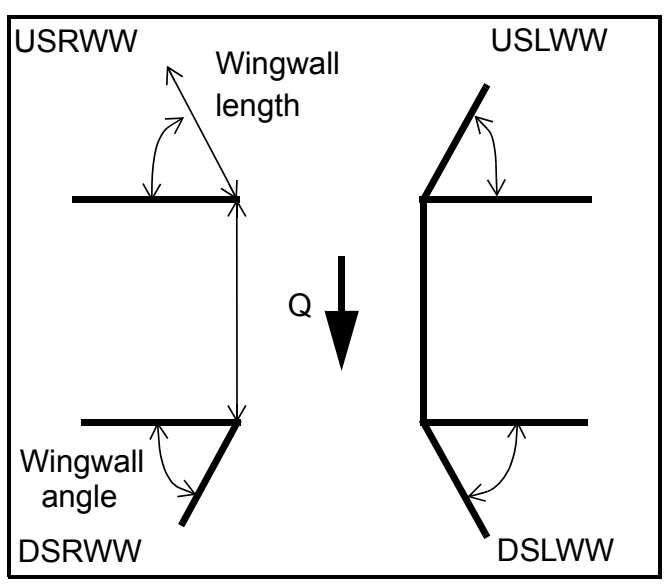

82. Bank / Bridge Protection:

\begin{tabular}{|l|l|l|l|l|l|l|l|c|}
\hline Location & USLWW & USRWW & LABUT & RABUT & LB & RB & DSLWW & DSRWW \\
\hline Type & - & - & N & - & - & - & $\mathbf{1}$ & $\mathbf{1}$ \\
\hline Condition & N & - & - & - & - & - & $\mathbf{4}$ & $\mathbf{4}$ \\
\hline Extent & - & - & - & - & - & $\mathbf{2}$ & $\mathbf{2}$ & - \\
\hline
\end{tabular}

Bank / Bridge protection types: 0- absent; 1- < 12 inches; 2- < 36 inches; 3- < 48 inches; 4- < 60 inches; 
83. Wingwall and protection comments (eg. undermined penetration, unusual scour processes, etc.):

-
-
-
-
-
-
-
-
-

\section{Piers:}

84. Are there piers? Th (Y or if N type ctrl-n pr)

\begin{tabular}{|l|l|l|l|l|l|l|l|}
\hline \multirow{2}{*}{$\begin{array}{l}85 . \\
\text { Pier no. }\end{array}$} & \multicolumn{3}{|c|}{ width (w) feet } & \multicolumn{3}{c|}{ elevation (e) feet } \\
\cline { 2 - 9 } & w1 & w2 & w3 & e@w1 & e@w2 & e@w3 \\
\hline Pier 1 & - & - & - & - & - & - \\
\hline Pier 2 & - & - & - & - & - & - \\
\hline Pier 3 & - & - & - & - & - & - \\
\hline Pier 4 & - & - & - & - & - & - \\
\hline
\end{tabular}

\begin{tabular}{|l|l|l|l|l|}
\hline Level 1 Pier Descr. & \multicolumn{1}{|c|}{1} & \multicolumn{1}{|c|}{2} & \multicolumn{1}{|c|}{3} & \multicolumn{1}{|c|}{} \\
\hline 86. Location (BF) & e abut- & nstrea & there & am \\
\hline 87. Type & ment & m & are & ends \\
\hline 88. Material & s are & ends. & also & of \\
\hline 89. Shape & pro- & In & some & the \\
\hline 90. Inclined? & tecte & addi- & type- & abut \\
\hline 91. Attack $\angle$ (BF) & d & tion & $\mathbf{3}$ & ment \\
\hline 92. Pushed & alon & to & boul- & s. \\
\hline 93. Length (feet) & - & - & - & - \\
\hline 94. \# of piles & g the & type- & ders & \\
\hline 95. Cross-members & upst & $\mathbf{2}$ & at & \\
\hline 96. Scour Condition & ream & pro- & the & \\
\hline 97. Scour depth & and & tec- & dow & \\
\hline 98. Exposure depth & dow & tion, & nstre & \\
\hline
\end{tabular}

LFP, LTB, LB, MCL, MCM, MCR, RB, RTB, RFP

1- Solid pier, 2- column, 3- bent

1-Wood; 2-concrete; 3- metal; 4- stone

1- Round; 2- Square; 3- Pointed

Y-yes; $N$ - no

$L B$ or $R B$

0- none; 1- laterals; 2- diagonals; 3- both

0- not evident; 1- evident (comment);

2- footing exposed; 3- piling exposed;

4- undermined footing; 5- settled; 6- failed 
99. Pier comments (eg. undermined penetration, protection and protection extent, unusual scour processes, etc.):

$\mathbf{N}$

$-$

100.

\section{E. Downstream Channel Assessment}

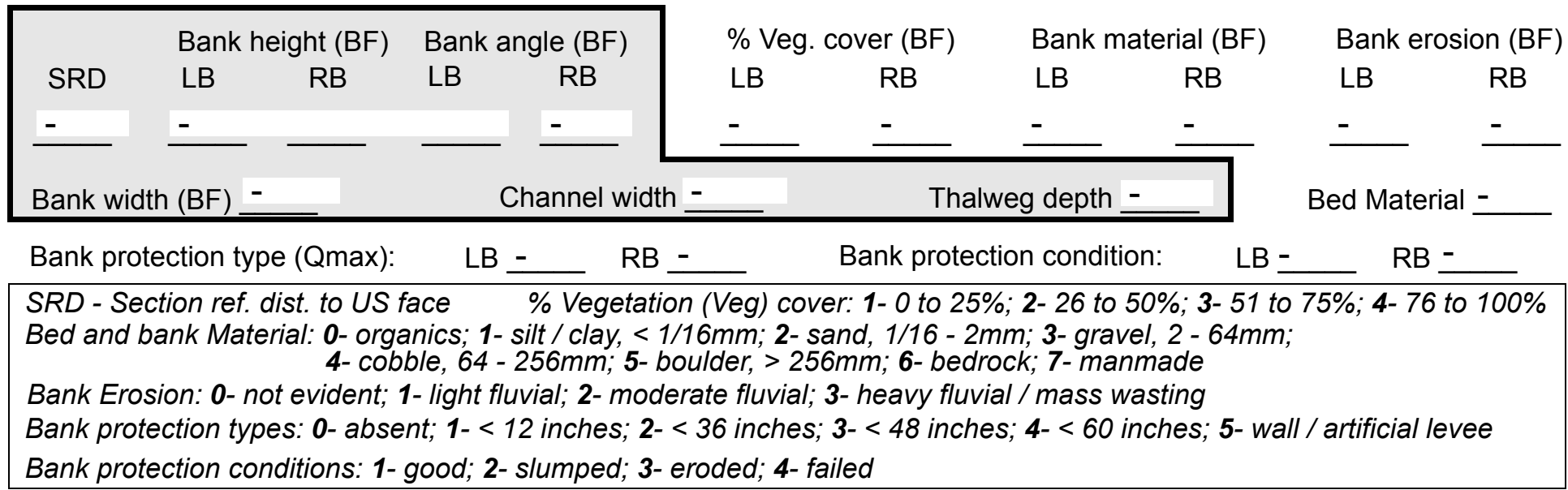

Comments (eg. bank material variation, minor inflows, protection extent, etc.):$$
-
$$

$-$

$-$

$-$

$-$

$-$

$-$

$-$

$-$

-

-

-

-

-

-

\section{Is a drop structure present? __ ( $Y$ or $N$, if $N$ type ctrl-n $d s) \quad$ 102. Distance: ___ feet}
103. Drop: - feet
104. Structure material:
(1- steel sheet pile; 2- wood pile; 3- concrete; 4- other)

105. Drop structure comments (eg. downstream scour depth):

-

-

-

$-$

-

$-$ 
106. Point/Side bar present? (Y or N. if N type ctrl-n pb)Mid-bar distance:

Mid-bar width: -

Point bar extent: feet (US, UB, DS) to feet (US, UB, DS) positioned $\%$ LB to $\%$ RB Material: $\mathbf{N O}$

Point or side bar comments (Circle Point or Side; note additional bars, material variation, status, etc.):

\section{PIERS}

Is a cut-bank present?

Cut bank extent: feet ( $Y$ or if $N$ type ctrl-n cb) Where? (LB or $R B$ ) feet $\underline{4}$ (US, UB, DS)

Bank damage: 3 (US, UB, DS) to (1- eroded and/or creep; 2- slip failure; 3- block failure)

Cut bank comments (eg. additional cut banks, protection condition, etc.): 3

3

0

0

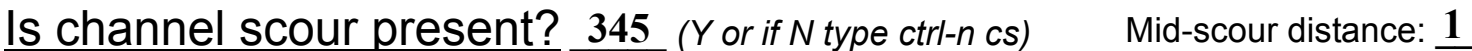
Scour dimensions: Length Width 1 Depth: 1

Scour comments (eg. additional scour areas, local scouring process, etc.):

$\mathrm{k}$ material is gravel, sand, cobbles and boulders. The bed material is gravel, cobbles and boulders. The DS banks have been built up with native streambed material. Bank protection on the left bank extends to $60 \mathrm{ft}$ DS and to $50 \mathrm{ft}$ DS on the right bank. The road is parallel to the stream on the DS right bank. At $200 \mathrm{ft}$ DS there is a trailer home on the right bank. The left and right banks are both shelved.

\section{Are there major confluences?}

Confluence 1: Distance

Confluence 2: Distance

Enters on

Enters on

Confluence comments (eg. confluence name): (Y or if $N$ type ctrl-n $m c)$ (LB or $R B)$ (LB or $R B)$
How many?

Type (1-perennial; 2- ephemeral)

Type (1-perennial; 2- ephemeral)

\section{F. Geomorphic Channel Assessment}

107. Stage of reach evolution
1- Constructed

2- Stable

3- Aggraded

4- Degraded

5- Laterally unstable

6- Vertically and laterally unstable 
108. Evolution comments (Channel evolution not considering bridge effects; See HEC-20, Figure 1 for geomorphic descriptors): $\mathbf{N}$

$-$

NO DROP STRUCTURE

$\mathbf{N}$

-

$-$

$-$ 


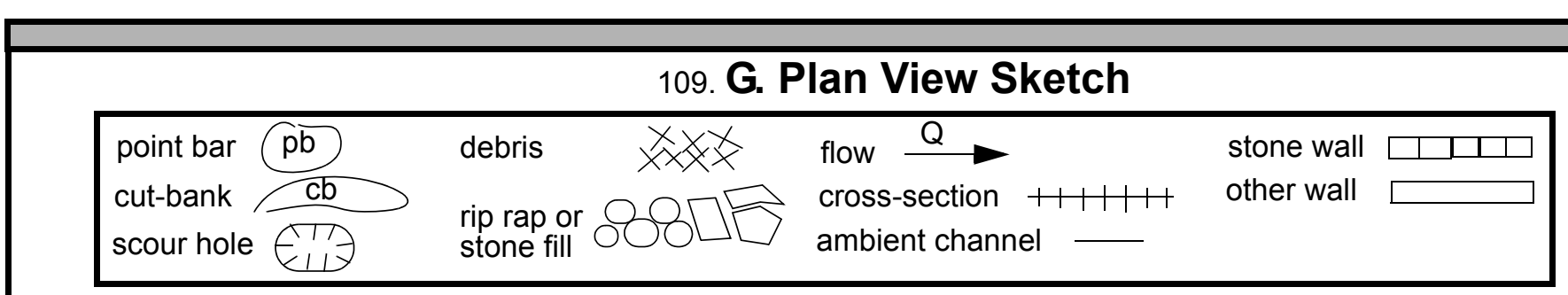


APPENDIX F:

SCOUR COMPUTATIONS 


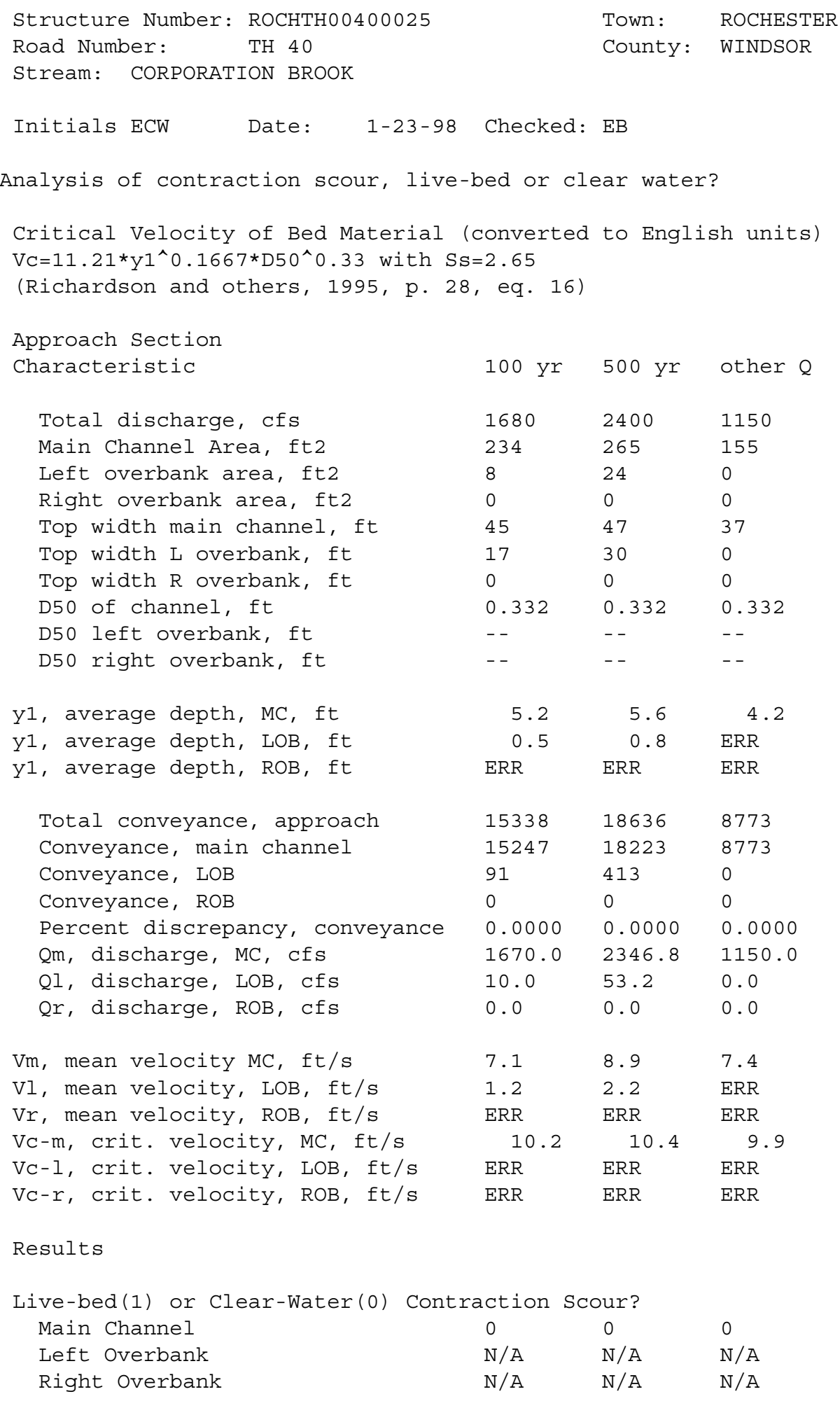


Clear water Contraction Scour in MAIN CHANNEL

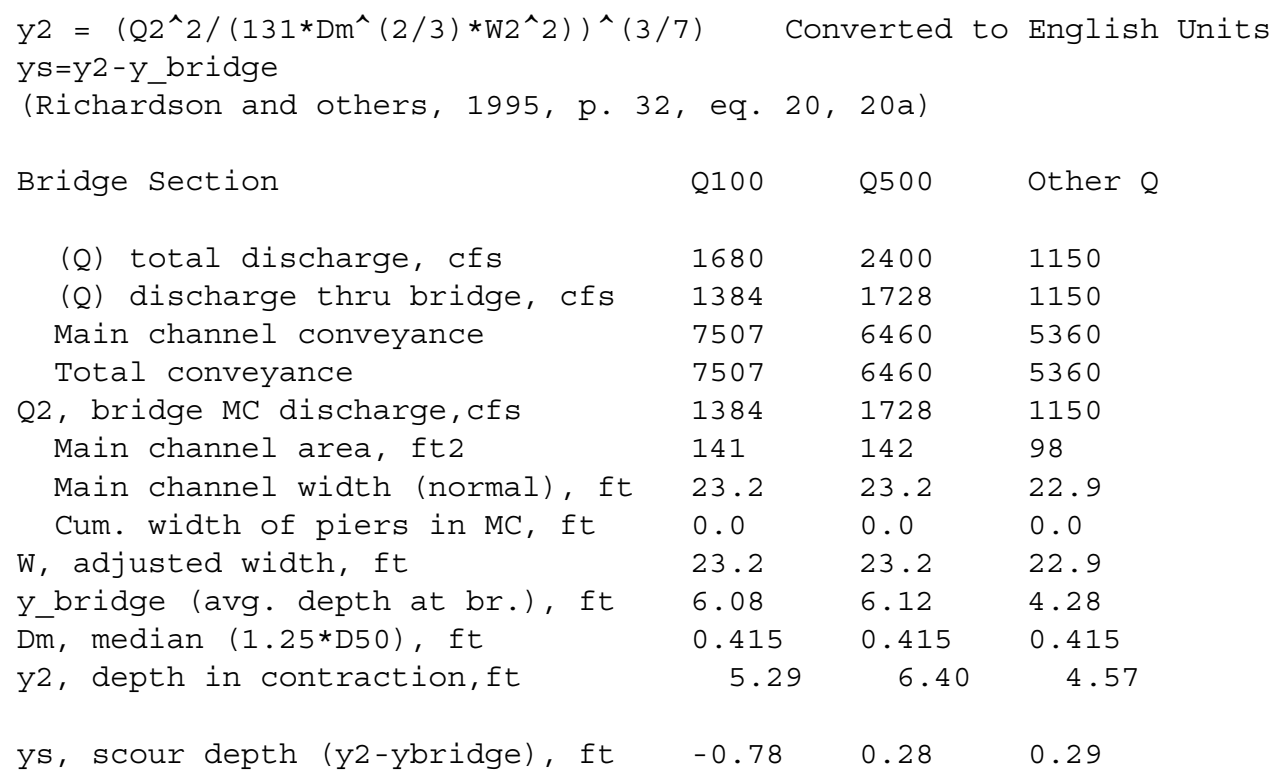

Armoring

$\mathrm{DC}=\left[\left(1.94 * \mathrm{~V}^{\wedge} 2\right) /(5.75 * \log (12.27 * \mathrm{Y} / \mathrm{D} 90))^{\wedge} 2\right] /[0.03 *(165-62.4)]$

Depth to Armoring $=3 *(1 / \mathrm{PC}-1)$

(Federal Highway Administration, 1993)

Downstream bridge face property 100-yr 500-yr Other Q

Q, discharge thru bridge MC, cfs $1384 \quad 1728 \quad 1150$

Main channel area (DS), ft2 $\quad 118 \quad 142 \quad 98$

Main channel width (normal), ft $23.2 \quad 23.2 \quad 22.9$

Cum. width of piers, ft $\quad 0.0 \quad 0.0 \quad 0.0$

Adj. main channel width, ft $23.2 \quad 23.2 \quad 22.9$

$\begin{array}{llll}\text { D90, ft } & 0.8362 & 0.8362 & 0.8362\end{array}$

D95, ft $1.0305 \quad 1.0305 \quad 1.0305$

$\begin{array}{lllll}\text { Dc, critical grain size, ft } & 0.7476 & 0.7399 & 0.8121\end{array}$

$\begin{array}{lllll}\text { PC, Decimal percent coarser than DC } 0.145 & 0.150 & 0.112\end{array}$

$\begin{array}{llll}\text { Depth to armoring, ft } & 13.18 & 12.62 & 19.35\end{array}$ 


\begin{tabular}{|c|c|c|c|c|}
\hline $\begin{array}{l}\text { Chang pressure flow equation } \\
\text { Cq=1/Cf*CC Cf=1.5*Fr^0.43 (<=1) } \\
\text { Umbrell pressure flow equation } \\
(\mathrm{Hb}+\mathrm{Ys}) / \mathrm{Ya}=1.1021 *[(1-\mathrm{w} / \mathrm{Ya}) *(\mathrm{Va} / \mathrm{VC})] \\
\text { (Richardson and other, } 1995, \mathrm{p} .144\end{array}$ & $\begin{array}{l}\mathrm{Hb}+\mathrm{Ys}=\mathrm{Cq} \\
\mathrm{CC}=\mathrm{SQRT}( \\
]^{\wedge} 0.6031 \\
-146)\end{array}$ & $\begin{array}{l}\text { * qbr/Vc } \\
0.10(\mathrm{Hb} /\end{array}$ & $(y a-w)-0.56)]+0.79$ & $(<=1)$ \\
\hline & Q100 & Q500 & OtherQ & \\
\hline Q, total, cfs & 1680 & 2400 & 1150 & \\
\hline Q, thru bridge $M C$, cfs & 1384 & 1728 & 1150 & \\
\hline Vc, critical velocity, ft/s & 10.22 & 10.36 & 9.86 & \\
\hline Va, velocity MC approach, ft/s & 7.14 & 8.86 & 7.42 & \\
\hline Main channel width (normal), ft & 23.2 & 23.2 & 22.9 & \\
\hline Cum. width of piers in MC, ft & 0.0 & 0.0 & 0.0 & \\
\hline W, adjusted width, ft & 23.2 & 23.2 & 22.9 & \\
\hline qbr, unit discharge, ft2/s & 59.7 & 74.5 & 50.2 & \\
\hline Area of full opening, ft2 & 141.0 & 142.0 & 98.0 & \\
\hline $\mathrm{Hb}$, depth of full opening, ft & 6.08 & 6.12 & 4.28 & \\
\hline Fr, Froude number, bridge MC & 0.71 & 0.89 & 0 & \\
\hline Cf, Fr correction factor $(<=1.0)$ & 1.00 & 1.00 & 0.00 & \\
\hline **Area at downstream face, ft2 & 118 & $\mathrm{~N} / \mathrm{A}$ & $\mathrm{N} / \mathrm{A}$ & \\
\hline **Hb, depth at downstream face, ft & 5.09 & $\mathrm{~N} / \mathrm{A}$ & $\mathrm{N} / \mathrm{A}$ & \\
\hline **Fr, Froude number at DS face & 0.92 & ERR & ERR & \\
\hline$* * \mathrm{Cf}$, for downstream face $(<=1.0)$ & 1.00 & $\mathrm{~N} / \mathrm{A}$ & $\mathrm{N} / \mathrm{A}$ & \\
\hline Elevation of Low steel, ft & 498.01 & 498.01 & 0 & \\
\hline Elevation of Bed, ft & 491.93 & 491.89 & -4.28 & \\
\hline Elevation of Approach, ft & 500.94 & 501.63 & 0 & \\
\hline Friction loss, approach, ft & 0.48 & 0.84 & 0 & \\
\hline Elevation of WS immediately US, ft & 500.46 & 500.79 & 0.00 & \\
\hline ya, depth immediately US, ft & 8.53 & 8.90 & 4.28 & \\
\hline Mean elevation of deck, ft & 499.5 & 499.5 & 0 & \\
\hline w, depth of overflow, ft $(>=0)$ & 0.96 & 1.29 & 0.00 & \\
\hline Cc, vert contrac correction $(<=1.0)$ & 0.95 & 0.95 & 1.00 & \\
\hline$* * C \mathrm{C}$, for downstream face $(<=1.0)$ & 0.895879 & ERR & ERR & \\
\hline Ys, scour w/Chang equation, ft & 0.10 & 1.48 & $\mathrm{~N} / \mathrm{A}$ & \\
\hline Ys, scour w/Umbrell equation, ft & 0.97 & 2.00 & $\mathrm{~N} / \mathrm{A}$ & \\
\hline
\end{tabular}




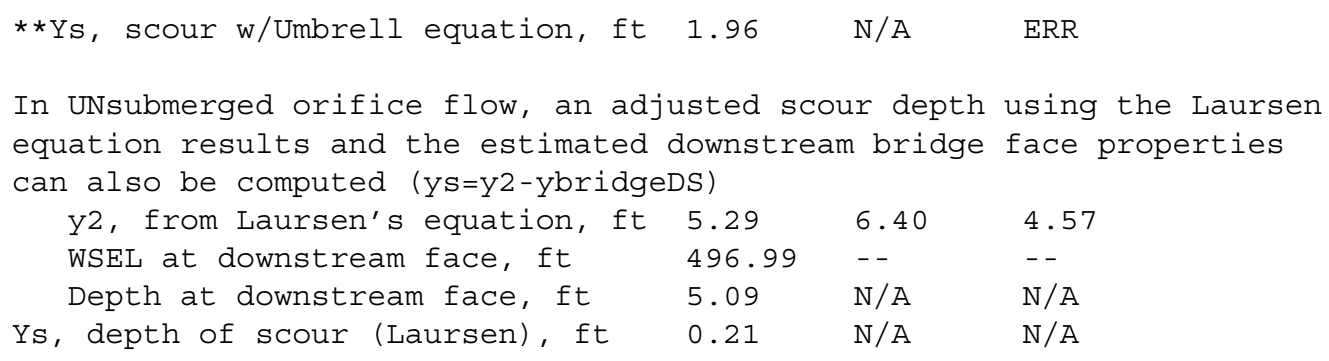

Abutment scour

Froehlich's Abutment Scour

$\mathrm{Ys} / \mathrm{Y} 1=2.27 * \mathrm{~K} 1 * \mathrm{~K} 2 *\left(\mathrm{a}^{\prime} / \mathrm{Y} 1\right)^{\wedge} 0.43 * \mathrm{Fr} 1^{\wedge} 0.61+1$

(Richardson and others, 1995, p. 48, eq. 28)

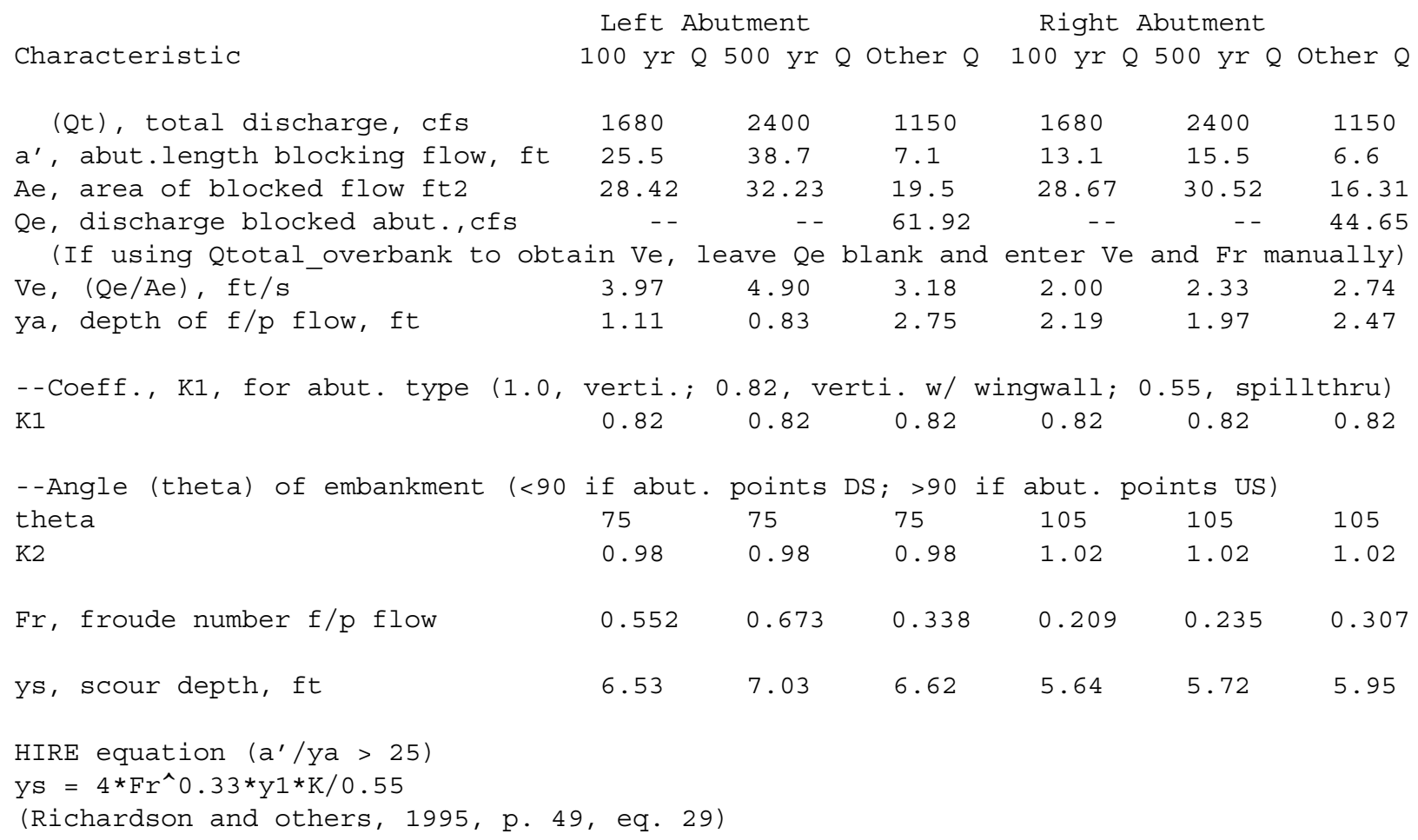




\begin{tabular}{|c|c|c|c|c|c|c|}
\hline a' (abut length blocked, ft) & 25.5 & 38.7 & 7.1 & 13.1 & 15.5 & 6.6 \\
\hline y1 (depth f/p flow, ft) & 1.11 & 0.83 & 2.75 & 2.19 & 1.97 & 2.47 \\
\hline$a^{\prime} / y 1$ & 22.88 & 46.47 & 2.59 & 5.99 & 7.87 & 2.67 \\
\hline Skew correction (p. 49, fig. 16) & 0.95 & 0.95 & 0.95 & 1.03 & 1.03 & 1.03 \\
\hline Froude no. f/p flow & 0.55 & 0.67 & 0.34 & 0.21 & 0.24 & 0.31 \\
\hline $\begin{array}{c}\text { Ys w/ corr. factor } \mathrm{K} 1 / 0.55: \\
\text { vertical }\end{array}$ & & & & & & \\
\hline $\begin{array}{l}\text { vertical } \\
\text { vertical w/ } w^{\prime} s\end{array}$ & $\begin{array}{l}\text { ERR } \\
\text { ERR }\end{array}$ & $\begin{array}{l}5.05 \\
4.14\end{array}$ & $\begin{array}{l}E R R \\
E R R\end{array}$ & $\begin{array}{l}E R R \\
E R R\end{array}$ & $\begin{array}{l}\text { ERR } \\
\text { ERR }\end{array}$ & $\begin{array}{l}E R R \\
E R R\end{array}$ \\
\hline spill-through & ERR & 2.78 & ERR & ERR & $\mathrm{ERR}$ & ERR \\
\hline Abutment riprap Sizing & & & & & & \\
\hline $\begin{array}{l}\text { Isbash Relationship } \\
\text { D50=Y*K*Fr^2/(Ss-1) and D50=Y*K* } \\
\text { (Richardson and others, 1995, p11 }\end{array}$ & $\begin{array}{l}\underbrace{\wedge} 2)^{\wedge} 0 . \\
\text { eq. }\end{array}$ & $\begin{array}{l}(S s-1) \\
2)\end{array}$ & & & & \\
\hline Characteristic & Q100 & Q500 & Other $Q$ & Q100 & Q500 & Other Q \\
\hline Fr, Froude Number & 0.92 & 0.89 & 1 & 0.92 & 0.89 & 1 \\
\hline$y$, depth of flow in bridge, ft & 5.09 & 6.12 & 4.28 & 5.09 & 6.12 & 4.28 \\
\hline Median Stone Diameter for riprap & $:$ left & utment & & right & abutment & ft \\
\hline Fr<=0.8 (vertical abut.) & ERR & ERR & ERR & ERR & ERR & ERR \\
\hline Fr>0.8 (vertical abut.) & 2.08 & 2.48 & 1.79 & 2.08 & 2.48 & 1.79 \\
\hline
\end{tabular}

